\title{
Teachers' views of the impact of the Good Start, Grow Smart Early Childhood Initiative on Head Start programs in a western Maryland community
}

\author{
Fannie L. Boayue \\ West Virginia University
}

Follow this and additional works at: https://researchrepository.wvu.edu/etd

\section{Recommended Citation}

Boayue, Fannie L., "Teachers' views of the impact of the Good Start, Grow Smart Early Childhood Initiative on Head Start programs in a western Maryland community" (2003). Graduate Theses, Dissertations, and Problem Reports. 2529.

https://researchrepository.wvu.edu/etd/2529

This Dissertation is protected by copyright and/or related rights. It has been brought to you by the The Research Repository @ WVU with permission from the rights-holder(s). You are free to use this Dissertation in any way that is permitted by the copyright and related rights legislation that applies to your use. For other uses you must obtain permission from the rights-holder(s) directly, unless additional rights are indicated by a Creative Commons license in the record and/ or on the work itself. This Dissertation has been accepted for inclusion in WVU Graduate Theses, Dissertations, and Problem Reports collection by an authorized administrator of The Research Repository @ WVU.

For more information, please contact researchrepository@mail.wvu.edu. 
Teachers' Views of the Impact of the Good Start, Grow Smart Early Childhood Initiative on Head Start Programs in a Western Maryland Community

\author{
Fannia L. Boayue
}

\begin{abstract}
Dissertation Submitted to the College of Human Resources and Education at West Virginia University In Partial Fulfillment of the Requirements for the degree of
\end{abstract}

Doctor of Education in

Curriculum and Instruction

Dr. J oy Faini Saab, Chair. Dr. Elizabeth Dooley Dr. Thomas J. Palardy Dr. Mary E. Haas Dr. Larry Stead

Department of Educational Theory and Practice Curriculum and Instruction Morgantown, West Virginia 2003

Keywords: Education, preschool, social policy 


\section{ABSTRACT}

Teachers' Views of the Good Start, Grow Smart Early Childhood Initiative on Head Start Programs in a Western Maryland Community

\section{Fannia L. Boayue}

As the call for accountability increased, President George W. Bush signed into law the No Child Left Behind Act in January 2002 to reform the Elementary and Secondary Education Act that was reauthorized in 1994. The Good Start, Grow Smart Early Childhood Education Initiative, followed in April 2002. Both of these reform measures have significant implications for school success and achievement of all children in both childcare and public school settings as well as accountability for teachers and administrators.

The purpose of this study was to investigate and analyze the views of Head Start teachers on the impact of the Good Start, Grow Smart Early Childhood Initiative on accountability for early literacy and language skills for Head Start children in a western Maryland community.

Five research questions asked in this study were related to Head Start teachers' professional experiences and background, personal characteristics, philosophical framework, strategies and methods of literacy and language practices with Head Start students and the impact of the Good Start, Grow Smart Early Childhood Initiative on Head Start teachers, administrators and students.

Data collection included the questionnaire and six one-hour long interview sessions with each Head Start teacher and administrator. Data were systematically and inductively interpreted in relation to the 
five research questions and with the perspectives of the administrator and teachers.

The study suggests that Head Start teachers and administrators believe that meeting the social-emotional and individual needs of Head Start students was critical in meeting the accountability requirements for language and literacy skills of the Good Start, Grow Smart Early Childhood Initiative. While the teachers generally expressed positive views about the need for the students to acquire language and literacy skill, they expressed some concerns because language and literacy were 'pushed' by the STEP training, and that might negatively impact social and emotional development of the students who are already atrisk due to their low-income background and poverty. Implications were drawn for Head Start teachers and administrators to consider possible risks of introducing young children to formal academic work prematurely. Directions for further research are suggested. 


\section{Acknowledgements}

Surviving the turbulence of the civil war that has ravaged my native country of Liberia for the past twelve years and to be at this point in my life is, to me, a true testimony to the enduring spirit of humankind. The will to persevere and thrive for success out of the ashes of utter destruction has been a challenge but a personal goal I did not lose sight of over these years. Although this goal seemed elusive many times, I believed my personal success would be an expression of remembrance for all my relatives and friends whose voices were forever silenced by the guns of war and in turn, signify the hopes I have for the children of war and peace, Liberia, and the future.

I would, therefore, like to acknowledge the following persons whose encouragement and support enable me to complete this dissertation.

The members of my doctoral committee, Dr. Elizabeth Dooley, Chair of the Department of Educational Theory and PracticeCurriculum and Instruction, West Virginia University, Dr. Thomas J. Palardy, Dr. Mary E. Haas, Dr. Larry Stead, and Dr. J oy Faini Saab, Chair of my doctoral committee, for literally being the wind beneath my often tired and broken wings and for your responsiveness when I needed you especially over these past months. Your helpful suggestions, comments and support were invaluable to me toward the completion of this significant phase of my life.

Dr. Joy Faini Saab, Associate Professor and Chair of my doctoral committee, for her guidance, mentoring, and above all, her true 
friendship. Throughout my doctoral study, I found strength in her kind words of understanding and encouragement whenever I faltered.

Mrs. Heather Davis, Director of Head Start-Human Resources Development Center, Allegany County, Maryland and Mrs. Robin Kerr, Assistant Director of Head Start-Human Resources Development Center, Allegany County, Maryland, for granting me access to Head Start teachers and for reprints of their internal assessment documents.

The Head Start administrator and teachers who gave me the opportunity to interview them concerning their educational practices with Head Start students. Sharing their philosophies and feelings with me was insightful and enlightening.

My family, including my bothers and sisters, Dr. Andrew K. Cole, Mr. Pei Mientoh Boayue, Dr. Charles Boayue, J r., Ms. Yei Boayue, Dr. Koh B. Boayue and Dr. Yao B. Cole who formed a shield of love around me and an enthusiastic you-can-do-it cheering section during this arduous period of research.

Sei Maakeh, my four-year-old son, who in many ways, is the expression of my hopes for the future and the constant reminder of my responsibilities to the young. As your name suggests, you are the reason for this accomplishment.

My father, Hon. Charles S. G. Boayue, Sr. who always told me that when I believe in myself and remained steadfast, I could achieve anything. Thanks "Pa", for being the forerunner who defined my educational path.

Most importantly, my mother, Mrs. Fannia Wannawon Boayue whose wise counsel has provided me with the framework for 
decision-making. Mommy, your love, understanding, and compassion have been the source of security, trust, determination, and well being throughout my education, even through war, and during challenging times. You have been my nurturer, anchor, moral guardian, and most significant model. Thanks for showing me that I can aspire to greatness because I am a woman. 
Title Page

Notice of Copyright i

Acknowledgements iv

Table of Contents vii

Chapter 1: Introduction 1

Statement of the Problem 1

Head Start: An Overview 2

Head Start Performance Standards 4

Standards of Learning for Head Start 6

The Head Start Program Studied $\quad 7$

The No Child Left Behind Act \& the Good

Start, Grow Smart Early Childhood Initiative 9

Project Step 10

Research Questions $\quad 11$

Definition of Terms $\quad 12$

Contribution of the Study 14

Limitations of the Study $\quad 14$

Summary 15

Chapter 2: Review of Literature 16

Introduction $\quad 16$

The No Child Left Behind Act \& The Good

Start, Grow Smart $\quad 17$

J ean Piaget: cognitive Development Theory 21

Vygotsky's Sociohistoric Theory and Learning 23

Emergent Literacy Development and the Influence of Adults 24

Language Development and the Influence 29

Of Adults

The Impact of Reading During the Early Years 31

Assessment and Accountability 32

Educational Reform and Early Childhood Education $\quad 37$

Assessment and Early Childhood Education 39

Appropriate Assessment in Early Childhood 
Education

The Strategic Teacher Education Program (S.T.E.P.):

A Professional Development

National Reporting System (NRS)

48

Summary

Chapter 3: Methodology

Introduction and Research Questions

53

Methods of Data Collection

55

Pilot Study of Interview and Questionnaire

Protocol

57

Participants

59

Setting

62

Procedures

62

Treatment of the Teachers' Interview Data

63

Treatment of the Interview Data from the

Head Start Administrator

65

Treatment of the Questionnaire Data

65

Summary

66

Chapter 4: Interpretation of Data 67

Themes of the Study

68

A personal description of the Head Start

Teacher and Administrator

69

Educational and Career Background

71

Educational Influences

76

A Philosophy of Teaching

79

Summary

82

The Head Start Teacher's Views on the Good Start,

Grow Smart

83

Assessment and Accountability

93

Instructional Methods

99

The Usefulness of Project STEP

104

Other Topics Emerging From the Data

108

Chapter 5: Implications

Head Start Teachers' Philosophy

The Head Start Teacher's Views on the Good Start, Grow Smart Early Childhood Initiative

Assessment and Accountability 
Usefulness of STEP

121

Implications of the Study

121

Future Directions for Research 128

References

131

Appendices

Appendix A: Cover Letter

142

Appendix B: Consent From

143

Appendix C: Interview Questions for Head Start Teachers

Appendix D: Interview Questions for Administrator

Appendix E: Questionnaire 


\section{Chapter 1}

\section{The Problem}

Introduction and Statement of the Problem

Reform in public education in the United States is not new. Over the years, reform laws have generally been aimed at various aspects of education including, among others, the quality of public education, the need for parent education, narrowing the achievement gap between students from minority populations and their middle class counterparts as well as between the advantaged and disadvantaged, the education of the disabled, and the need for teachers and administrators to be accountable for the progress and achievement of students. In recent federal legislation on public education, school reform has increasingly focused on accountability based on results for all students including children during early childhood.

As the call for accountability increased, President George W. Bush signed into law the No Child Left Behind Act in January 2002 to reform the Elementary and Secondary Education Act that was reauthorized in 1994. The Good Start, Grow Smart Early Childhood Education Initiative, followed in April 2002. Both of these reform measures have significant implications for school success and achievement of all children in both childcare settings and public school settings as well as accountability for teachers and administrators in these settings.

While education remains the primary responsibility of the states, the role of the federal government in ensuring that all children in the United States have access to a free public education cannot be overemphasized in public education. To this end, the federal government's 
commitment has continued through its funding to the states for such programs as Title One and Head Start.

Although some measurable outcomes for student achievement have been noted as a result of implementing Head Start programs, the voices of the teachers and administrators who are the practitioners and the accountable persons for the success of reform policies need to be documented, especially now when new policies are being implemented. The purpose of this study was to investigate and analyze the views of Head Start teachers on the impact of the Good Start, Grow Smart Early Childhood Initiative on accountability for early literacy and language skills for Head Start children in a western Maryland community.

\section{Head Start: An Overview}

Head Start, a federally funded program, was launched in 1965 under the Head Start Act. It was designed to break the cycle of poverty by providing preschool children of low-income families with a comprehensive program to meet their emotional, social, intellectual, health, nutritional, and psychological needs. At Head Start, children age three to school entry age receive these services in urban and rural areas in all 50 States, the District of Columbia, Puerto Rico, and the U. S. Territories, including many American Indians and migrant children. According to the HHS (U.S. Department of Health and Human Services, 2002), in fiscal year 2002, Head Start served 857,664 children.

In order to meet the needs of the diverse population of people served, Head Start established four component areas to help it meet 
its goals. The four components are education, health, parent involvement, and social services.

In the education component of Head Start, the educational program is designed to meet the needs of each child. Every child receives a variety of learning experiences to foster intellectual, social, and emotional growth. The educational program also serves the community and its ethnic and cultural characteristics.

Early identification of health problems for each child is emphasized. A comprehensive health program is provided for every child including, immunization, medical, dental, mental health, and nutritional services.

Another critical and essential part of Head Start is parent involvement. Parents receive training and education that foster their understanding of and involvement in the development of their children. It is required that parents be involved in education, program planning, and operating activities including policy councils and managerial decisions. Also parent participation in classes and workshops on child development and staff visits to the parent's home are expected. All these services enable parents to fulfill their role as their children's primary caregivers and move toward self-sufficiency.

Finally, after each family's needs have been determined, specific social services are set up for the family including, recruitment and enrollment of children, community outreach, family need assessments, referrals and emergency assistance and/or crisis intervention.

In the Head Start Act Amendments of 1994, Early Head Start was established. Since then, Head Start has enrolled children from birth to age three in the Early Head Start program. Early Head Start 
expands the benefits of early childhood development to low-income families with children under three years of age and to pregnant women.

To be eligible for Head Start (HHS, 2003), the child must meet the age and family income criteria. The child must be age three to age five to meet the age criteria. The family income criteria stipulate that the family income must be at or below the federal poverty line. In 2003 , the poverty line was $\$ 8,980$ for a family unit of one, the income was at or below $\$ 8,980$, a family unit of 4 was $\$ 18,400$, and a family unit of 8 was $\$ 30,960$. For family units with more than eight persons, an additional $\$ 3,140$ would be added.

Although Head Start is intended to primarily serve children from families with income at or below the poverty line, the program's regulations permit up to ten percent of the children from families who are not low-income and also require that a minimum of ten percent of enrollment be made available to children with diagnosed disabilities.

\section{Head Start Performance Standards and Objectives}

Critical components of Head Start include training and technical assistance to assist local projects in meeting the Head Start Performance Standards (HHS, 2000). As such, the training and technical assistance help to maintain and improve the quality of local programs, research, demonstration, and evaluation activities to test innovative program models and assess program effectiveness.

The Head Start Performance Standards are the key regulations that set the guidelines and standards for quality in Head Start programs nationwide. Both Head Start and Early Head Start must comply with these federal standards. The Performance Standards 
were designed to ensure that all children and families receive highquality services. The Performance Standards guide program development and implementation and cover child health, developmental services, education, early childhood development, child health, safety, child nutrition, child mental health, family, community partnerships, program management and program governance. While the Head Start Bureau provides guidance on meeting the performance standards, local agencies are responsible for designing programs to best meet the needs of their children and families.

The performance standards also define five inter-related objectives for Head Start and they are: to enhance children's growth and development, strengthen families as the primary nurturers of their children, provide the children with educational, health, and nutritional services, link children and their families to needed community services, and ensure well-managed programs that involve parents in decision making (HHS, 2000).

Finally, the performance standards stress that local programs emphasize the professional development of Head Start teachers and include reading and math readiness skills in the curriculum.

Standards of Learning for Head Start

In the 1999 Head Start reauthorization, congress mandated that Head Start programs implement nine standards of learning (The White House, 2002), in three areas. The three areas were, literacy, language and numeracy. The standards of learning for Head Start children are:

1. to develop phonemic, print, and numeracy awareness.

2. to understand and use language to communicate for 
various purposes.

3. to understand and use increasingly complex and varied vocabulary.

4. to develop and demonstrate an appreciation of books.

5. in the case of non-English-background children, progress toward acquisition of the English language.

6. to know that the letters of the alphabet are a special category of visual graphics that can be individually named.

7. to recognize a word as a unit of print.

8. to identify at least ten letters of the alphabet.

9. to associate sounds with written words.

The nine standards of learning are implemented in four specific domain elements namely, phonological awareness, book knowledge and appreciation, print awareness and concepts, and number and operations. The domain elements and standards of learning are part of the Head Start Child Outcome Framework (ACF, 2000). The Head Start Child Outcome Framework outlines specific indicators for what children at Head Start should learn and be able to do.

\section{The Head Start Program Studied}

The Head Start Program investigated in this study was located in a rural community in western Maryland, USA. Those interviewed in this study were all employed by the administration of the Head Start Program investigated in this study. There was a total of 13 teachers serving the entire Head Start program of which eleven teachers had the baccalaureate degree in elementary education or early childhood 
education. The two other teachers had their Associate of Arts (AA) credentials and one of the two had been a teacher for over thirty years.

During the 2002-2003 school year, the investigated Head Start Program served a total of two-hundred and fifty-nine students and forty-four of the students had individualized education plans (IEP). All students enrolled at the investigated Head Start met the eligibility criteria described earlier in this chapter.

Following the 1999 Head Start reauthorization, the investigated Head Start Administration implemented the use of the standards of learning in language, literacy, and numeracy. The Standards of Learning was used by teachers for instructional purposes for the first time during the 2000-2001 school year and was still used by the teachers at the time of this study.

Since each program was mandated to implement an internal assessment of the students in the 1999 reauthorization, the investigated Head Start Administration also implemented the Human Resources Development Center (HRDC) Head Start Early Childhood Observation Record commonly referred to as the report card (HRDC, 2002). Each student was assessed, on the report card, in eight domain elements including, language, literacy, mathematics, science, creative arts, social and emotional development, approaches to learning, and physical health and development. The standards of learning assessed on the report card were the same standards of learning required by the Good Start, Grow Smart Early Childhood Initiative in language and literacy. During the school year, the report card was used three times to record student progress and 
accomplishments. The initial reporting, done in October, was used to establish the baseline data to determine areas of need for individual students. The next, assessment was done in January and a final assessment completed at the end of the school year. The report card also had a special section for both parents and teachers to write their comments. The report card was shared with the parents of students during scheduled conferences with the teachers.

Another internal assessment method used was the anecdotal record. Each teacher was also required to observe and record daily anecdotal information on individual students. This information was used to provide teachers with additional data on students' progress and accomplishments.

A final method used for internal record keeping and reporting was the portfolio. Based on the work sampling system (Meisel, Jablon et al.,1995), the teacher created a portfolio of samples of the student's work and products and the portfolio demonstrated the student's performance, progress, and accomplishments.

\section{The No Child Left Behind Act and the Good Start, Grow Smart Early} Childhood Initiative

In J anuary 2002, the latest legislation for public school reform was signed into law by President George W. Bush. This law, known as The No Child Left Behind Act, NCLB (The White House, 2002), was aimed at reforming the Elementary and Secondary Education Act (ESEA) that was reauthorized in 1994. The law addressed four critical components for improving K-12 education: accountability for results, unprecedented state and local flexibility and reduced red tape, focusing 
resources on proven educational methods, and expanded choices for parents.

While the NCLB Act ensured that K-12 students learn what they need to know to be successful in life and that public schools were providing students with the skills to be successful, the law also recognized the need for early education and that students should be prepared before they start school. Such an educational preparation should enable young children to begin school with an equal chance at achievement because they have the necessary skills to be successful in learning school subjects. Since young children received care and education in a variety of settings outside of the public schools including Head Start, it was important to document that pre-school age children were also being served as part of the NCLB Act. In other words, reforms in K-12 education implied similar reforms in early childhood education.

Hence, the President, in April 2002, announced the Good Start, Grow Smart Early Childhood Initiative (GSGS), with three focused major areas with specific implications for Head Start. The focused areas were: strengthening Head Start to ensure that every Head Start center assesses standards of learning in early literacy, language, and numeracy skills; partnering with states to improve early childhood programs so that these programs deliver quality programs; and providing information to teachers, caregivers and parents to close the gap between the best research and current practices in early childhood education.

Together, the No Child Left Behind Act and the Good Start, Grow Smart Early Childhood Initiative (GSGS), have significant implications 
for what young children learn, how they learn it and the educational practices of all Head Start teachers.

\section{Project STEP}

To carry out the mandates of the NCLB and the GSGS, the Head Start Bureau instituted the Strategic Teacher Education Project (Project STEP). The ultimate goal of project STEP was to enhance school readiness and positive child outcomes. Hence, with the use of specifically targeted Federal funds, the Head Start Bureau convened the Head Start Conference for STEP Early Literacy Mentor-Coaches (HHS, 2002). STEP began training Early Literacy Specialists in May and was launched in June, 2002. Throughout the summer of 2002, 32 hours of literacy training was provided to over 3,000 Head Start education managers and state childcare managers. These participants were trained as Early literacy Mentor-Coaches and charged with returning to their programs to provide similar training to classroom colleagues and to mentor-coach those colleagues. Mentor-coaches would provide and support local Head Start staff with knowledge and skills in child development, early literacy, language, numeracy, and social and emotional development. Fifteen training sessions for the Mentor- Coaches were held across the United States and Puerto Rico.

\section{Research Questions}

The purpose of this study was to investigate the views, perceptions, and concerns of Head Start teachers in one community toward the Good Start, Grow Smart Early Childhood Initiative. The impact the GSGS would have on them and their efforts to provide 
appropriate educational experiences and tasks for the young children in their classrooms were also investigated.

The following research questions were formulated to investigate the impact of the Good Start, Grow Smart initiative as a reform mechanism and how it will influence educational practices of Head Start teachers.

Question 1:

What experiences and influences have contributed to Head Start teachers' views of education and of themselves as teachers of young children?

Question 2:

In what ways do Head Start teachers' view the Good Start, Grow Smart Early Childhood Initiative? How is it similar to or different from the current Head Start Program?

\section{Question 3:}

In what ways do Head Start teachers demonstrate accountability for students' achievement and success in literacy and language learning?

Question 4:

What emergent literacy and language experiences do teachers provide for their students?

Question 5:

What changes occurred in Head Start teachers' provision of literacy and language learning experiences for their students because of Project STEP? 


\section{Definition of Terms}

For the purpose of this study, the following terms were defined. STEP

Is the acronym for the Strategic Teacher Education Project instituted by the Head Start Bureau to train all Head Start teachers so that every classroom teacher has a fundamental knowledge of early development as well as in the areas of language, literacy and numeracy skills in order to meet the requirements of the Good Start, Grow Smart Early Childhood Initiative.

\section{Teacher}

The adult individual with the primary responsibility for providing care and education to every young child in Head Start and Early Head Start classrooms. In this study, the term teacher is used interchangeably with Head Start Teacher.

\section{Early Literacy}

A set of behaviors and concepts that develop into conventional literacy including pre-reading experiences with print, writing and speech that children have by which they learn to construct and communicate meaning. In this study, early literacy is used interchangeably with emergent literacy.

\section{Early Literacy Mentor-Coach}

An individual who has received STEP training for the purpose of providing effective support and guidance to Head Start program staff. In this study the term early literacy specialist is used interchangeably with mentor-coaches.

\section{Early Childhood}

The period of an individual's life spanning birth to age five. 


\section{Young Children}

Individuals who fall within the ages from birth to the age of eight. In this study, the term young children, is used interchangeably with preschool aged children.

\section{Quality services}

The implementation of all mandated services addressed by the Head Start Performance Standards without any deficiency.

\section{Deficiency}

An area of performance in which an Early Head Start or Head Start Agency is not in compliance with state or Federal requirements including, but not limited to, the Head Start Act, or one or more regulations under parts 1301, 1304, 1305, 1306, or 1308.

Standards of Learning

A set of nine indicators mandated by Congress for what Head Start students should learn and be able to do.

\section{Contributions of the Study}

This study will be helpful in identifying and clarifying significant factors unique to Head Start teachers and administrators and the children they serve. In addition, it will provide educators with helpful information for understanding some of the underlying attitudes and beliefs of Head Start teachers that contribute to the degree of success for a certain educational reform. Specifically, it will contribute to an understanding of accountability for Head Start students' progress and achievement based on results. The study will help to affirm or dispel assumptions about Head Start teachers' attitudes toward their role as teachers of disadvantaged children and 
toward education. Results from the study will assist administrators, educators, and program planners in evaluating the specific program approaches of STEP and their potential impact on student outcomes.

\section{Limitations of the Study}

This research used a case study methodology to yield descriptive information for an in-depth exploration of the participants.

All participants in this study volunteered their participation in the study. This suggests, therefore, that those individuals may be of a different mind-set than those not inclined to volunteer for participation in such a study. Also, there is the possibility of a varying level of interest and involvement in the Good Start, Grow Smart Early Childhood Initiative by the participants in the study.

All the participants in this study were residents of the same county in one Mid-Atlantic state. Therefore, results are not generalized to other regions of the country without benefits of a replication study in another geographical area with a different population.

Additionally, this study's results may not be generalized to other Head Start programs with a different delivery system. Teachers in this study delivered services in a center-based Head Start program. Head Start programs with a home-based delivery system may affect participants' behaviors in different ways. Therefore, there may be different outcomes for participants receiving center-based services then those receiving home-based services. 


\section{Summary}

This chapter dealt with Head Start and the influences of recent educational reform on Head Start. Head Start is a comprehensive Federal program that primarily serves low-income children and their families. However, with the current emphasis on reforms based on accountability for students' success in language, literacy, and numeracy, the need for Head Start teachers to implement changes in how they delivered services to students were considered in new and different ways.

This study sought to explore the views of Head Start teachers on the impact of the Good Start, Grow Smart Early Childhood Initiative on accountability for early literacy and language skills for Head Start children in a western Maryland community. 


\section{Chapter 2}

\section{Review of Literature}

Introduction

This chapter includes a review of the research literature on the development of language and literacy skills of young children especially during the pre-school years. It provides information related to the purpose of the present study and the focus of the research questions on the views of Head Start teachers on the impact of the Good Start, Grow Smart on accountability for literacy and language skills development and accomplishment of Head Start students. The background of this study, the Congressional legislation known as the No Child Left Behind Act and the Good Start, Grow Smart as school reform policies, are presented.

The three major areas of the Good Start, Grow Smart provided the focus for this research. Literature is presented on professional development and its impact on teachers of young children in order to provide a framework for understanding Project STEP. The theories of J ean Piaget and Lev Vygotsky were used to form the framework for understanding how young children construct knowledge and how those theories influenced instructional practices that were developmentally appropriate for young children.

Literature about educational reform, assessment, accountability, and early childhood education were presented to provide a context for the Good Start, Grow Smart relative to the accountability of Head Start teachers for language and literacy skills development, the accomplishment of their students, and the National Reporting System. Research in the field of emergent literacy and language were provided 
for an understanding of the processes of early literacy and language development in young children. Other research was presented on teachers' instructional behaviors and practices that influence the development of language and literacy skills of young children.

The No Child Left Behind Act and the Good Start, Grow Smart

In January 2002, President George W. Bush signed the latest legislation for public school reform into law. This law, The No Child Left Behind Act (NCLB), was aimed at reforming the Elementary and Secondary Education Act (ESEA) that was reauthorized in 1994. It addressed four critical components for improving K-12 education (The White House, 2002):

(1) Accountability for results-to create strong standards in each state for what every child should know and learn in reading and math..., statewide reports will show progress for all student groups in closing achievement gaps between disadvantaged students and other groups of students, and schools will be held accountable for improving performance of all student groups, so that every school will be performing at proficient levels within twelve years (p.1).

(2) Unprecedented State \& Local Flexibility \& Reduced Red Tape- provides new flexibility for all 50 states and every local school district in America in the use of federal education funds. States will have the freedom to target up to 50 percent of federal non-Title One dollars to 
program that will have the most positive impact on the students they serve... (p. 1).

(3) Focusing Resources on Proven Educational Methods focused educational dollars on proven, research-based approaches that will most help children learn. This includes a new Early Reading First program to support early language, literacy, and pre-reading developments of preschool-age children, particularly those from low-income families... (p. 1).

(4) Expanded Choices for Parents- enhances options for parents with children in chronically failing schools and makes these options available immediately in the 2002-03 school year for students in thousands of schools already identified as failing under current laws (pp. 1-2).

While the NCLB Act claims it will ensure that K-12 students learn what they need to know to be successful in life and that public schools will be providing students with the skills to be successful, the Bush Administration also recognized the need for early education and that students should be prepared before they start school. It is expected that this early educational preparation will enable young children to begin school with an equal chance at achievement and with the necessary skills to learn so that no child is left behind. Since young children receive care and education in a variety of settings outside of the public schools including Head Start, it was important to document 
that pre-school age children were also being served as part of the NCLB Act. In other words, reforms in K-12 education implied similar reforms in early childhood education.

Hence, the President, in April 2002, announced the Good Start, Grow Smart Early Childhood Initiative (The White House, 2002), with three focused major areas:

(1) Strengthening Head Start- through the Department of Health and Human Resources (HHS), the Administration will develop a new accountability system for Head Start to ensure that every Head Start Center assesses standards of learning in early literacy, language, and numeracy skills. HHS will also implement a national training program with the goal of training the nearly 50,000 Head Start teachers in early literacy teaching techniques (p. 2).

(2) Partnering with States to Improve Early Childhood Education- The Administration proposes a stronger Federal-State partnership in the delivery of quality early childhood programs. This new approach will ask States to develop quality criteria for early childhood education, including voluntary guidelines on pre-reading and language skills activities that align with State $\mathrm{K}-12$ standards. To help States meet these criteria, States will have more flexibility with their Federal childcare funds (p. 2).

(3) Providing information to Teachers, Caregivers, and Parents: in order to close the gap between the best 
research and current practices in early childhood education, the Department of Education will establish a range of partnerships as part of a broad public awareness campaign targeted toward parents, early childhood educators, and child care providers, and other interested parties. To assist this effort, the Bush Administration supports an unprecedented \$45 million research collaborative between the National Institute of Child Health and Human Development and the Department of Education to identify effective pre-reading and language curricula and teaching strategies (p. 2).

Together, the No Child Left Behind Act and the Good Start, Grow Smart initiative suggested the need for pre-school age children to acquire skills in early language, literacy, and numeracy. They also suggested that accountability for results through high standards and improved educational methods were all critical for the educational success and achievement of all students

The first five years of a child's life is a critical time for children's development and learning (National Association for the Education of Young Children, 1998; Slegers, 1996). Educators of children recognize that what a child learns between the ages of birth to age five will form a significant basis for later learning and school success. During these years, children develop and acquire skills in all areas of development including, physical, emotional, cognitive, social, and language. Growth and development in these areas are interconnected such that growth in one area influences growth in other 
areas. Other areas in which the child's needs are present include health, safety and nutrition. Hence, early learning experiences should be comprehensive and holistic to parallel the developmental patterns of the child's growth and at the same time ensure growth in all areas of development.

The purpose of this investigation was to study and analyze the views of Head Start teachers on the impact of the Good Start, Grow Smart Early Childhood Initiative on accountability for early literacy and language skills of Head Start students in a western Maryland Community.

Jean Piaget: Cognitive Developmental Theory

In the education of children during the early childhood period, a major theorist whose work has influenced instructional practice is J ean Piaget. His work has contributed to our understanding of how children think and learn (Piaget, 1952, 1955). He recognized language as a tool children use for cognitive development, although initially, language in itself according to Piaget, did not contribute to the development of thought. Thus, in his stage theory, cognitive developmental theory, Piaget described how children progress from primitive uses of symbols and verbalizations to sophisticated mechanisms for representing the world.

During Piaget's first stage of cognitive development, the sensory-motor stage spanning the periods approximately from birth to two years, Piaget maintains that both operational thought and language have their roots in the sensory-motor period. During this time, children learn that words are tied to activities. Symbolism, according 
to Piaget, appears in other forms prior to the emergence of language. Thought is the natural foundation for the development of language as a human system of communication.

The second stage, the preoperational period spanning age two to seven years, is marked by children's use of symbols to represent objects and their experiences. Language develops during the preoperational stage with children using increasingly complex sentence structure and tremendous vocabulary growth. Children learn to use various kinds of symbols to replace objects. Drawing, scribbles, blocks and all kinds of concrete objects become whatever the child wants it to be.

A basic but important premise in cognitive developmental theory (Piaget, 1952), is that children learn through active participation and the child "constructs" his or her own understanding of the world through interaction with it. In other words, learning is a continuous structuring process. As children grow, they continue to adapt to new experiences transforming their knowledge through a process of assimilation and accommodation. Accordingly, assimilation is to understand the new experience through existing mental structures and accommodation is the process of adapting the mental structures to the new. Finally, adaptation occurs when there is equilibrium between assimilation and accommodation, which requires the child's active participation.

While Piaget's cognitive developmental theory does not explain language acquisition, language itself provides children with experiences that help them build mental structures for understanding. Likewise, pictures and printed language provides children different types of 
symbolic representation of objects and experiences that are the primary modes of representation in school.

\section{Vygotsky's Sociohistoric Theory and Language}

Another theorist whose work has informed our knowledge of how children learn is Lev S. Vygotsky. Vygotsky (1962) examined children's learning and elaborated on the importance of human interactions on learning. He studied higher-order and conscious processes during learning from a sociocultural approach. He believed (1987), that the development of higher-order thinking is mediated by human interaction and by cultural tools such as literacy, speech, and mathematics that are historical and social in use. According to Vygotsky, learning leads development with a gradual progressive unfolding of the meaning inherent in language through the interaction of speech and thought. Also, language stimulates learning and "thought is born through words" (1962, p. 153).

The social context is critical for children's development. This is reflected in Vygotsky's belief that the constraints of the social environment determine the forms of learning used (1987). For him, conceptual growth depends on interactions with people and objects in the environment. Therefore, social interaction promotes the development of verbal meaning.

The adult's instructional role in children's learning is also a critical component of the sociohistoric theory. Vygotsky described the "zone of proximal development" as the areas between the child's actual developmental level and the level of potential development (1978). It is an area in which a child can accomplish tasks with help. 
Consequently, within this proximal zone, adults can provide "scaffolding" or support for children to move ahead to more complex learning.

Furthermore, because of the zone of proximal development, adults are the major force for stimulating children to expand beyond their current functioning. Adults can facilitate development by providing names, instructions and suggestions to children. Also by encouraging children's external speech, adults promote planning and conceptualization for the child. In his investigations, Vygotsky found that children use external speech to help them understand difficult problems.

Finally, the theories of J ean Piaget and Lev Vygotsky are used to form the foundation for assumptions of this study. These theories recognize children's active participation and the construction of meaning as key processes of learning. The interaction with important adults such as teachers, specifically in this study, as stimulus for cognitive growth is another important premise of this study.

\section{Emergent Literacy Development and the Influence of Adults}

The term emergent literacy was first used by Marie Clay (1966) to describe the behaviors used by young children with books and when reading and writing, even though the children could not actually read and write. Until that time, it was believed that children must learn to read before they could learn to write. Current studies such as Schickedanz (1998), affirmed this view that there was no need to postpone children's functional writing until they all knew the alphabet letters. Some children developed strong writing skill simply through 
exposure to a print-rich environment. Over the years the term emergent literacy has replaced reading readiness and refers to reading and writing experiences in the early childhood years, which are precursors of conventional literacy.

The foundations of literacy development begins earlier than when children learn to read and write formally. Morrow and Rand(1993) explained that the concept of emergent literacy encompasses the interrelatedness and concurrent development of reading, writing, and oral language. Similarly, the Idaho Center on Developmental disabilities (1996) documented, for example, that by age 2 or 3 many children can identify signs, labels and logos in their homes and in their communities and that reading and writing develop at the same time and interrelatedly in young children.

Literacy development is a complex and dynamic process. It is a dimension of language and is a part of an integrated language process in a social context. It involves understanding the "functions of literacy- knowing that letters spell words and knowing words have meaning- as an important part of learning about reading and writing during early childhood as forms of literacy- naming specific letters or words" (Council for Exceptional Children, 1996, Teale \& Sulzby, 1986).

Literacy development evolved gradually through exposure to and interaction with print materials and other persons who use print materials in the daily contexts of the home, school, and community (Morrow \& Rand, 1993). According to Schickedanze (1986), literacy learning proceeds naturally if the environment supports young children. Children's early symbols usage in talking, during play and fantasy, in scribbling and drawing, and in pretend reading and writing help them 
represent experiences, feelings and ideas. By playing with writing and reading, children become familiar with the tools of literacy and begin to learn how to use and control them (McLane \& McNamee, 1991).

Experts emphasized that literacy was not simply an accumulation of specific skills related to reading and writing. Rather, literacy involved the ability to make, interpret and communicate meaning (Ferreiro \& Teberosky, 1983; McLane \& McNamee, 1991). Reading is the ability to construct meaning from print and writing is the ability to use print to communicate with others. McLane and McNamee contended, therefore, that becoming literate involves not only mastering a set of decoding skills but also mastering a set of attitudes, expectations, and behaviors related to written language.

Other experts suggested that before children learned to read, they needed to be aware of how sounds worked in spoken language. That is, phonemic awareness- the ability to think and work with individual sounds in spoken languages (National Institute for Literacy, 2001). While Stanovich (1993-94) found that phonemic awareness is the best predictor of the ease of early reading acquisition and appears to play a causal role in reading acquisition, it is not a sufficient condition for learning to read. Adams (1990) described five levels of phonemic awareness and suggested that it is critical for children to be able to link phoneme awareness to a knowledge of letters. According to the National Reading Panel (2000), phonics skills must be integrated with the development of phonemic awareness, fluency, and text reading comprehension skills because developing skill in blending and manipulating phonemes permit many children to develop strong reading abilities. Some ways in which this can be accomplished are; while a 
child writes, the teacher can name the letters or comment about the strokes used to form the letters, teachers should provide flexible writing experiences that allow young children to use scribble, random letters, or invented spelling in the beginning, and over time to move to more conventional forms (NAEYC, 1998; Teale \& Yokota, 2000). Thus, when children write their own text in these ways, they are developing their vocabulary and phonemic awareness (Slegers, 1996). Yopp (1992) suggested some ways for the instruction of phonemic awareness activities. The suggestions to teachers include (1) keeping a sense of playfulness and fun and avoiding drill and rote memorization, (2) use group settings that encourage interaction among children, (3) encourage children's curiosity about language and their experimentation with it, (4) allow for and be prepared for individual differences, and (5) make sure the tone of the activity is not evaluative but rather, fun and informal.

In Van Kleeck (1990), the point is made that the mere exposure to literacy materials is not sufficient for the development of literacy. The critical characteristic for literacy development is the adult-child interaction around such events that is important. Literacy learning is socially mediated and the same is true for language learning. Thus, Teale (1982) said “... the whole process of natural literacy development hinges upon the experiences the child had in reading and writing activities which were mediated by literate adults, older siblings or events in the child's everyday life" (p. 559).

To enable children to acquire literacy abilities, Holdaway (1979) provided four processes. The first process is observation of literacy behaviors through being read to by an adult or seeing adults read and 
write. The second is collaboration with and individual who interacts with the child. Third, is when the child tries out alone what has been learned through such activities as role playing or invented spelling. Through such experimentation and practice, children can evaluate their performance and increase skills. The fourth process is performance in which the child seeks approval from interested and supportive adults.

Young children's literacy learning benefits greatly from adults who are responsive to their interests and sensitive to their current level of language development (Slegers, 1996). Young children need many one-on-one interactions with caring adults to support their oral literacy development. Books, papers, writing tools, and functional signs should be visible everywhere in the classroom so that children can see and use literacy for multiple purposes. They also need teachers to play with, talk with, sing to, and with whom to do finger plays and other learning games. In such an environment, Slegers adds that teachers can draw children's attention to specific letters and words in the environment whenever appropriate and provide time for children to explore literacy.

In preschool, young children need positive and nurturing relationships with teachers who can model reading and writing behaviors, engage in responsive conversations, and foster their interests in learning to read and write (NAEYC, 1998; Teale \& Yokota, 2000). Finally, when literacy is an integral part of their daily activities, children actively construct their own literacy knowledge and strategies and learn to read and write naturally and playfully (Teale \& Yokota, 2000). 


\section{Language Development and the Influence of Adults}

The studies of several researchers were used to provide the framework for understanding language development during the early years in this study.

Halliday (1975), described language development as a way children "learn to mean". In this theory, Halliday suggested that children learn that language is a tool that serves them when sharing ideas and feelings in life. Language helps direct daily functions of living and is a social process. Accordingly, Halliday identified seven functions found in the oral language of children: (1) informative language, which is used to communicate information to others, (2) instrumental language, which is used to satisfy needs to get things done, (3) interactional language, which helps children build a bond with others, (4) regulatory language, which controls the behaviors of others, (5) personal language, which is used to tell about oneself, (6) imaginative language, which is used to pretend, and (7) heuristic language, which helps children to explore the environment.

In Holdaway (1979, 1986), another framework for an understanding of language is provided. In this study, Holdaway described the learning process as a dance. In this dance, adults talking about activities help the child explore and the adults become part of the learning environment. As part of the learning environment, adults create activities that are part of the everyday environmental structures in which the child lives, adults serve as models for expected behaviors, provide appropriate intervention to facilitate children's attempts to master and achieve understanding of skills, and the adults 
are ready to shift roles and become the learner as the child displays newly acquired behaviors.

Cazden (1983) provided another framework for understanding language development in the early years. In his study, Cazden described three ways that adults shape children's language learning. The first way is through scaffolding, a term used to characterize adult assistance to children's language development. A scaffold is a framework for construction in progress. One kind of scaffold, vertical construction, is when the adult asks the child for additional new information in each utterance.

Another kind of scaffold, game-like routines, is apparent in adult-child conversations in the early years in language games with infants. The adult creates a sequential structure with slots of certain shapes in which the child comes to speak such as in the game of peeka-boo. Picture book sharing is also a ritualized speech event wherein talk is the primary purpose. The book provides clear and present references for labels. As the child's development proceeds, the adult encourages the child to speak more.

Adults also shape language by modeling. How adults speak indicates how texts are constructed for particular purposes and in particular situations. According to Cazden (1983), adults who are literate not only supply models through reading to children, but they also coach young children in such narrative accounting by speaking for them before they can speak for themselves. This, for example, is seen when an adult gives a running narrative of an activity that is taking place. A way in which adults provide assistance in language learning to 
young children is direct instruction in which the adult directs the child to say or spell or ask.

Fillmore and Snow (2000) assert that teachers need an understanding of language. They distinguished five functions which are central to the teacher's work in language: (1) teachers are communicators, (2) teachers are educators, (3) teachers are evaluators, (4) teachers are educated people, and (5) teachers are agents of socialization. Fillmore and Snow argued that teachers' knowledge about language will enhance teachers' practice in general, and in particular, it will aid them in teaching literacy. Also, the teachers' knowledge will aid them in working with English language learners (August \& Hakuta, 1998).

\section{The Impact of Reading During the Early Years}

Reading books to children has been identified as the one early experience that makes a difference in later learning to read in school (Anderson, Hiebert, Scott \& Wilkinson, 1985). Wells (1986) found that of several literacy-developing activities, the one most outstanding in its relationship to literacy formation and reading test scores was listening to stories.

When children are read to in natural environments, they create frameworks for stories in their minds. Children learn that stories progress from a beginning to an end. According to Glazer and Burke (1993), children learn the following from listening to story reading: (1) how the written language system works, (2) what print represents, (3) what are the purposes of books, (4) what reading is, (5) that stories can be written down, (6) that there is some correspondence 
between sounds and symbols on the pages, (7) how to predict what stories are about, and (8) how to remember stories and data from text.

Furthermore, Holdaway (1979) added that children learn written language and oral language when they are read to. For example, written language has distinctive structures, which do not appear in spoken dialects. Children also learn that books will be interesting, challenging, exciting, and comforting. Additionally, children re-enact or recapture the meaning of stories in their play.

Another impact of storybook listening is that children learn specific ways of "taking from text" (Teale, 1984). For example, adults may relate story events to the child's own life. Thus, pleasure and enjoyment from sharing books is experienced by children as they feel the warmth of the adults who loved them and who hold them close. Glazer and Burke pointed out that the emotional experiences occurring during story time link feelings and reading.

\section{Assessment and Accountability}

Assessment and accountability have both played important roles in educational reform efforts during the past 50 years. During the 1950s, testing was used to select students for higher education and to identify students for gifted programs. Also, test results were used as one measure to evaluate the effectiveness of Title One and other federal programs by mid-1960. According to Linn, (2000), during the 1970 s and early 1980s, the minimum competency testing movement requiring some sort of testing of basic skills as a graduation requirement began. This movement continued and overlapped with the 
expansion and use of standardized test results for accountability during the 1990s.

The Good Start, Grow Smart Early Childhood Initiative is an effort to reform early childhood education, including Head Start, in the United States. The first basic focus of this reform effort was that every Head Start center will assess students on the standards of learning in early literacy, language, and numeracy through an accountability system developed by the Department of Health and Human Services, (HHS). A second focus of this reform stipulated a stronger FederalState partnership in the delivery of quality early childhood programs in which states, with more flexibility with their Federal child care funds, will develop quality criteria for early childhood programs and a third focus was on providing information to teachers, caregivers, and parents.

During the 1998 reauthorization of Head Start, the nine standards of learning were mandated for Head Start children (The White House, 2002), and they included (1) the development of phonemic, print, and numeracy awareness, (3) understand and use increasingly complex and varied vocabulary, (4) develop and demonstrate an appreciation of books, (5) in the case of non-English background children, progress toward acquisition of the English language, (6) know that letters of the alphabet are a special category of visual graphics that can be individually named, (7) recognize a word as a unit of print, (8) identify at least 10 letters of the alphabet, and (9) associate sounds with written words. Policy makers believed that these standards of learning will ensure that all children will then begin school with the skills they need to succeed in school. 
Linn (2002), found four reasons that suggest significant appeal for assessment by policymakers. Those reasons are (1) assessment is relatively inexpensive compared to making program changes, (2) it can be externally mandated, (3) it can be implemented rapidly, and (4) assessment offers visible results.

In the discussion of assessment and education reform, Linn suggested three critical characteristics of reform efforts that need to be considered throughout the process: (1) the emphasis on the development and use of content standards as the basis of assessment and accountability, (2) the emphasis on setting demanding performance standards and on the inclusion of all students, and (3) the attachment of high-stakes accountability mechanisms for schools, teachers, and sometimes students.

Policymakers need to understand the strengths and weaknesses of content standards. An inherent issue is that content standards vary in specificity and in emphasis. However, content standard should influence the choice of construct to be measured and the ways in which they are eventually measured (Education Week, 1997; Olsen, 1998; Raimi \& Braden, 1998). For example, the construct to be measured mattered because content areas, and sub areas within those content areas, that are assessed for high-stakes accountability, received emphasis while those that are left out languish.

A second characteristic to consider is performance standards. According to Linn, performance standards have at least four critical characteristics. First, performance standards are intended to be absolute rather than normative. Second, they are expected to set high, world-class levels. Third, a small number of levels, such as 
satisfactory and proficient, are typically identified and, fourth, performance standards are expected to apply to all students. The concern, according to Coffman (1993) is that performance standards tend to hold common high standards for all students. He believed that this can become problematic because "holding common standards for all pupils can only encourage a narrowing of educational experiences for most pupils, doom many to failure, and limit the development of many worthy talents" (p. 65). Finally, having high standards is not the same as having common standards for all, especially when high standards are tied to a lock step of age or grade level.

The final characteristic for consideration is high-stakes accountability systems. While this is not a new phenomenon in educational reform, it is somewhat different in the current discourse on performance-based accountability. According to Elmore, Abelmann, and Fuhrman (1996) "what is new is an increasing emphasis on student performance as touchstones for state governance" (p. 65). Student achievement is increasingly being used not only to single out schools that require special assistance, but also to provide incentives for improvements in performance. To this end, Meyer (1996) argued, "in high-stakes accountability system, teachers and administrators are likely to exploit all avenues to improve measured performance. For example, teachers may 'teach narrowly to the test'. For tests that are relatively immune to this type of corruption, teaching to the test could induce teachers and administrators to adopt new curriculums and teaching techniques much more rapidly than they otherwise would" ( $p$. 140). 
A second area of concern regarding high-stakes assessments is related to what data the basic model should employ. Again, Elmore et al. (1996), present two sides of this issue. They noted that schools can fairly be held accountable only for those factors they can control but on the other hand, controlling for student background or prior achievement institutionalizes low expectations for poor, minority, and low-achieving students. Guskey (1994), found that Kentucky responded to this dilemma by setting a common goal for all schools by the end of twenty years. This approach established faster biennial growth targets for initially low-scoring schools than initially highscoring schools.

Therefore, to enhance the validity, credibility, and positive impact of assessment and accountability systems while minimizing their negative effects, Linn (2000), suggested that policy makers should (1) provide safeguards against selective exclusion of students from assessments, (2) don't put all the weight on a single test, instead, seek multiple indicators since the choice of construct matters and the use of multiple indicators increases the validity of inferences based upon observed gains in achievement, (3) place more emphasis on comparisons of performance from year to year than from school, (4) consider both value added and status in the system since value added provided schools that start out far from the mark a reasonable chance to show improvement while status guided against institutionalizing low expectations for those same students and schools, and (5) put in place a system for evaluating both the intended positive effects and the more likely unintended negative effects of the system. 


\section{Educational Reform and Early Childhood Education}

As proposals for educational reform increased and the emphasis on academic achievement and preparation for technological change is heightened, it came as no surprise that the most recent reform legislation the No Child Left Behind Act and the Good Start, Grow Smart Early Childhood Initiative, both emphasized academic achievement and accountability. Although the reasons for such emphasis in education are varied, they have significant impact on early childhood education.

Sigel (1987) found that many administrators and parents were raising achievement standards for young children. Teachers were also being pressured to alter curriculum and instruction, and young children were being hurried to acquire knowledge and skills earlier than was typical. Other sources of pressure for young children to achieve came from parents. Sigel noted that parents pressured their children for various reasons including their own ambitions for achievement, that is the parents' own need for help with multiple responsibilities especially if they are single, and the anxiety about the uncertain, highly competitive futures children face, (1987). There had also been some broad changes in social values, which seemed to be sustaining this momentum for academic achievement. As noted by Marie Winn (1981) and Edith Douvan (1985), heightened expectations for young children may signal a change in the nation's view of children such that Americans may no longer see childhood as a unique period of development requiring special nurturance. Also, adult interests may become paramount to those of young children. 
When educational reform with this emphasis was applied to the primary school and downward, according to Katz (1987), results were varied including an acceleration of formal academic instruction, for example, earlier introduction to reading and math, complete with texts and workbooks. Furthermore, there may be entry and placement tests for kindergarten and first grade involving standardized or other tests for promotion to first grade, and the need for transitional or extrayear programs for children who cannot keep up, (1987). While affluent children may receive an excess of enrichment such as special tutoring in the arts and fast-paced educational programs, children in low-income families may face stringent standards in school.

Several studies have found that the emphasis on academic achievement for young children may be harmful to their mental, physical and social welfare. It may also be counterproductive for longrange educational goals. Children need time and space to actively organize their knowledge, apply it to new events, and relate ideas about time, space, number and persons. David Elkind (1986), and Sigel (1987), found that accelerating young children forced them to rely on lower-level cognitive processes, for example, memorization and visual recognition of letters and numbers, which could stultify learning and even damage self-esteem and confidence. Children learn on their own pace and must have suitable social and educational experiences to develop normally. Also, it may be short sighted to trade human complexity and creativity, according to Minuchin (1987), for accelerated academic learning in early childhood. 
Assessment and Early Childhood Education

The release of A Nation At Risk by the National Commission on Excellence in Education (1983), began a national era to upgrade the quality of American schools at all levels. With this came the calls for reform based in higher standards. Since then, educators in the various disciplines, including Mathematics, Science, English, Social Studies and Reading have established standards for the knowledge, skills and dispositions students should learn. However, the specificity of curriculum standards varied across subjects.

Historically, American schools have been committed to conducting specified educational processes, not to producing outcomes. In such education, according to Conley (1993), emphasis was placed on seat time rather than students' actual knowledge. He believed that standards should reflect the minimum expectations society holds for schools and should have two components: contentsrelated component and process-related component. The contentrelated component should reflect mastery of the information base of a recognized discipline or body of knowledge, and the process related component should describe the intellectual process consisting of attitudes, behaviors, and skills that may be applied to a wide variety of content in the process of information. Schools should have appropriate methods for evaluating both components, (1993). Thus, O'Neil (1991), argued that time spent in classroom and minimum competencies, as reflected on standardized tests, must be replaced with better indicators of students' accomplishments. In addition, Ravich (1992), found that some schools have gone beyond traditional testing procedures adopting innovative forms of assessment such as 
portfolio reviews of past work, projects, and performance evaluation which may better reflect what a student has learned than examinations.

Many studies have suggested that in order to reform the educational system, schools must implement high standards for student achievement that stress performance. Sizer and Roger found that since schools are accountable to the public, the development and implementation of standards should be a communal process involving many voices, (1993). The Education Commission of the States, (1992) suggested that the voices include parents, educators, representatives of higher education, and business as well as school boards. With performance as a focus, standards will become a means of translating broad visions of improvements into more specific parameters for outcomes. The expected outcomes will then encourage students to strive for higher levels of achievement and provide benchmark for measuring the success of reform efforts.

Finally, according to the Commission on Chapter One (1993), while there existed varying views on how best to use standards for student achievement, there was evidence to suggest that when students are encouraged to work with challenging content under optimum teaching and learning conditions, students will make far greater progress than those students who received basic skill instruction. Welch (1992), found that standards that assume all students can learn more and can learn at high levels guarded against the self-fulfilling prophecy of low achievement that low standards produced. Also, Welch noted that standards were an effective defense against parental complacency that undermined student achievement. 
Thus, when standards were adopted and woven into the whole fabric of the education system, it provided a basis for implementing reforms and enabled schools to reclaim their unique role of education.

\section{Appropriate Assessment in Early Childhood Education}

Many studies have found that the assessment of young children present challenges. In one such study, Jensen (1998), found that traditional methods of assessment, such as standardized tests, put enormous pressure on children and pressure can inhibit thinking. Also, Shepard (1994), and Ratcliff (1995), found that the younger the child being evaluated, assessed, or tested, the more errors are made.

Other studies suggested there were risks to young children associated with early academic instruction. Schweinhart and Weikart (1997), and Macon (1995), found that the introduction of academic work into early childhood curriculum yielded fairly good results on standardized tests in the short term but may be counterproductive in the long term. For example, the risk of early instruction in beginning reading skills is that the amount of drills and practice required for success at an early age seemed to undermine children's disposition to be readers. Another risk of introducing young children to formal academic work prematurely and noted by Bendura et al. (1999), is that those who cannot relate to the tasks required are likely to feel incompetent and may come to consider themselves as being stupid.

Within the current discourse on reforming early childhood education, the emphasis is on accountability based on results. There seemed to be pressure to demonstrate effectiveness through children's performance on standardized tests which does not only 
change how teachers teach and what children study but it also seemed to be changing our very understanding of the nature of learning and achievement (McGill-Franzen \& Arlington, 1993). The tests hold power and the concern is that they rob teachers of their sense of judgment about how to help children develop to their optimal potential. In a study by Stallman and Pearson (1990), this loss of judgment was often observed in the readiness and early school achievement tests whose content were generally abstract, verbally mediated, and potentially biased against children who are unfamiliar or uncomfortable with testlike activities.

Not withstanding, in early childhood education, assessment of young children's progress and achievement of standards can be documented in active, engaged learning experiences. As such, assessment should be developmentally appropriate (NAEYC, 1997; Neuman \& Clay, 2000), meaning that assessment and assessment practices should consider the individuality of the child, the age of the child, and the child's culture. In Katz (1995), assessment should also include knowledge, skills, dispositions, and feelings and should be done during children's informal work and play so that errors are minimized. During the preschool years, and early primary grades, children learn best through active, engaged, meaningful experiences through which young children construct their own knowledge (Labinowicz, 1980).

The development of positive dispositions toward learning in the early years is also important. As described by Bruner (1996), Katz (1987), and Smith (1990), when we teach young children, we not only provide opportunities to learn knowledge and skills, but also to develop attitudes and dispositions about the use of that knowledge and those 
skills. Thus, the development of dispositions becomes critical for the long-term attainment of high standards.

As noted by Caine \& Caine (1997), insights from brain research have suggested that learning was easier when experiences were interconnected rather than compartmentalized into narrow subject areas. Teaching strategies such as complex thematic units and the Project Approach (Katz \& Chard, 1989), provided this integration and intellectual challenge for young children. Young children learned from these hands-on, thought-provoking experiences because the experiences engaged their curiosity, motivated them to apply their developing skills, and challenged children to think reflectively.

According to Stiggins (1994), performance assessment was the type of educational assessment in which judgments were made about student knowledge and skills based on observation of student behavior or inspection of student products. The Work Sampling System (WSS), (Meisels, Dorfman, and Steele, 1995), offered an approach that documented activities in which young children engaged on a daily basis. The WSS is an exemplar of performance assessment and how performance assessment worked in Head Start, early childhood, and the primary years (Meisels, Jablon, et al., 1995). The WSS assessed and documents children's skills, knowledge, behavior, and accomplishments across a wide variety of educational domains and as manifested on multiple occasions. It has three main components: (1) developmental guidelines and checklists which assist teachers in observing, creating and documenting profiles of individual children's growth and progress, (2) portfolios designed to provide rich documentations of each child's experiences illustrating their efforts, 
progress, and achievements throughout the year, and (3) the summary reports, done three times a year, is a means of translating the rich information from developmental checklists and portfolios into a more easily understood and interpreted document for parents, teachers, and administrators.

According to Meisels, Liaw, Dorfman, and Fails (1995), the WSS provided teachers with reliable and valid data about children's school performance and with a great deal of information and evidence about children's activities and development that can be used to enhance instruction and to report to children's parents. It allowed teachers to record what children can do in the context of the children's experience. Finally, the WSS offered children, teachers, parents, administrators, and policy makers an opportunity to view the sweep and power of children's growth and development integrating instruction and assessment.

The Strategic Teacher Education Program (S.T.E.P.): A Professional Development Program

With the increased demand for school reform and the changing face of the US student population, there is a need for all teachers to learn more about the role of language and literacy in teaching and learning. This knowledge can enhance teachers' practice and improve their ability to teach literacy. In addition, this knowledge can increase teachers' effectiveness with students who speak languages other than English and dialects other than Standard English.

Teaching and learning are complex and teachers need time to learn and experiment with new concepts in the classroom just as their 
students do. According to Rueda (1998), principles of effective teaching and learning for students extend to effective professional development for teachers. To be successful, professional development must be long-term and it must incorporate opportunities for learning that centers on teachers and students.

Hawley and Valli (1999) suggested eight principles of effective professional development: (1) it should be driven by an analysis of teacher's goals and student performance, (2) it should involve teachers in the identification of what they need to learn, (3) it should be school based, (5) it should be continuous and adequately supported, (6) it should be information rich, (7) it should include opportunities for the development of theoretical understanding, and (8) it should be part of a comprehensive change process.

Head Start has always used a comprehensive approach to childhood development focused on social, emotional and cognitive development of the child. The primary focus in this approach is the child achieving the social competence to be able to deal with their present environment and later responsibilities in school life (HHS, 2002).

Following the enactment of the No Child Left Behind Act of 2002, The Good Start, Grow Smart Early Childhood Initiative (GSGS) was announced by the Bush Administration to strengthen early learning and to ensure that all young children were equipped with the skills they needed to start school ready to learn (The White House, 2002). The GSGS particularly outlined ways for improving early childhood development programs within Head Start to prepare children with language and literacy skills so that the children can succeed in school. 
Therefore, Head Start has now broadened its curriculum scope to include language and literacy development as areas of emphasis for the children they serve.

In order to fulfill this mandate, the Head Start Bureau launched Project STEP, the Strategic Teacher Education Program, (Head Start Bureau, 2002). The STEP is a comprehensive, multi-faceted, sequential professional development endeavor (Lyon \& Pinell, 2001). STEP is focused on training local Head Start program managers as literacy trainers. The goal of the Head Start Bureau in developing STEP is to give every Head Start teacher the skills (Nueman, Copple, \& Bredekamp, 1999; Hyson, 2001) needed to foster early literacy and language in Head Start and ensure that every Head Start program has a baseline from which to grow and implement their local curriculum. STEP also ensured that programs had access to the resources they need to be successful by providing supplemental funds to all Head Start programs participating in STEP efforts.

The STEP is conducted and delivered by the University of Texas Health Sciences Center at Houston's Center for Improving the Readiness of Children for Learning and Education, (C.I.R.C.L.E.). The philosophy of STEP encompasses the best of whole language and direct instruction blended together. Training topics include approaches to teaching strategies, optimum classroom arrangements, and use and placement of materials to promote children's literacy and language learning.

STEP provides nationwide research-based literacy training for all Head Start programs, builds on existing quality improvement and professional development efforts, and creates a consistent foundation 
of staff knowledge and skills in early literacy to enhance the locally designated curriculum and staff development efforts.

The STEP approach includes four components designed to expand and extend the skills and techniques used by Head Start teachers (Head Start Bureau, 2002): (1) coaching and mentoring in the classroom, (2) evidence-based strategies to support children's social and emotional development, to guide challenging behaviors, and to improve child outcomes, (3) an excellence in teaching summit in summer 2003, and (4) distance-learning technology including satellite broadcast, web casts, CD-ROMs, and small group learning experiences.

During the summer and fall of 2002, more than 3,000 Head Start staff and many Child Care representatives and program directors completed 32 hours of STEP training and became Early Literacy Mentor-Coaches, formally known as Early Literacy Specialists. After completing STEP training, the Early Literacy Mentor-Coaches returned to their local programs to provide training for their local teachers.

Early Literacy Mentor-Coaches provided similar STEP training for their classroom colleagues and mentor-coached the classroom teachers. Mentor-coaches provide and support local Head Start teachers with knowledge and skills in child development, early literacy, language, numeracy, and social and emotional development. Training topics include: best practices, phonological awareness, written expression, motivation to read/read aloud, book knowledge and letter knowledge (Schikedanz, 1999; West et al. 1998; Nyberg, 1996; Clay, 1993). Each training session included a total of 25-35 teachers and mentoring intended to be done with lead teaching staff on an on-going basis throughout the year. 
Mentor-Coaches increased the internal capacity of Head Start agencies to meet the Head Start Performance Standards and to support positive child outcomes as described in the Head Start Child Outcomes Framework (Head Start Bureau, 2002). They observed and assessed the learning environment and provided individualized coaching and one-on-one modeling for classroom teachers.

\section{National Reporting System (NRS)}

While STEP ensured that Head Start teachers used the best instructional methods for teaching the standards of learning in language, literacy, and numeracy through training, there was a need for ways in which students' progress and achievement of the standards of learning would be documented for accountability. In the Good Start, Grow Smart initiative (The White House, 2002), each Head Start program was required to assess all enrolled children between the ages of 3 and 5 on the standards of learning at the beginning, middle, and end of each year and were also required to analyze the assessment data on the progress and accomplishments of all the enrolled students.

Likewise, the HHS was directed in the Good Start, Grow Smart to develop an accountability system to collect data from local programs. The data collected would be used for two purposes: (1) to target new staff training and program improvement to enhance the capacity for Head Start to increase children's early literacy and school readiness, and (2) the data would be used by HHS to evaluate the local program's contract (The white House, 2002). 
This new accountability system, the National Reporting System on Child Outcomes (HHS, 2003), was field-tested in 36 diverse Head Start programs with more than 1,400 children during the 2002-2003 academic year and announced for implementation to Head Start and Early Head Start Agencies on June 26, 2003. At the time of this study, appropriate changes were being made to the results from the field-test before seeking final approval from the Office of Management and Budget (OMB). Consequently, Head Start agencies were advised not to begin to assess children until the HHS provided the assessment instruments with valid OMB control numbers. At the time of this study, the local Head Start program had not received the final NRS document.

The NRS was not intended for use in assessing the school readiness of individual children, nor was it to be used to replace locally designed on-going child assessment efforts done for the purposes of curriculum planning, individualization, and communication with parents.

The design of The National Reporting System (NRS), is based on the Good Start, Grow Smart Early Childhood Initiative and provisions of the Head Start Act (sections 641A.(a) (1)(B), 641A. (b)(4), 641A.(c)(2)(D), 648(c)(1)(B), 649.(b)(4)) (HHS, p.2). The NRS created a new data base on the progress and accomplishments of all 4and 5-year-old Head Start children on a common NRS assessment at the beginning and end of the program year to determine some of the skills with which the child entered Head Start, the progress they made during the Head Start year, and their levels of achievement when they leave Head Start. Head Start programs are expected to include all 4and 5-year-old children including children with identified disabilities, all 4-and 5-year-old children served through the various Head Start 
program design options, and all 4-and 5-year-old children who speak either English or Spanish or both. The NRS provides data on five of the nine standards of learning mandated by Congress in the Head Start Act of 1998 (HHS, p.3):

(1) Understanding and using language to communicate for various purposes.

(2) Using increasingly complex and varied vocabulary.

(3) In the case of children whose native language is other than English, progressing toward acquisition of the English language.

(4) Identifying at least 10 letters of the alphabet.

(5) Numeracy awareness.

The research bases for the NRS came from the assessment instruments and findings of the Family and Child Experiences Survey (FACES, 2000). Furthermore, the tasks in the assessment are intended to appraise skills that (1) are critical stepping-stones on the path to achievement in elementary school, especially in the areas of reading and mathematics, (2) can be readily enhanced by activities in Head Start, (3) Head Start parents want their children to learn, (4) a majority of US children from non-low-income families have mastered by the time they begin kindergarten, and (5) can be reliably measured in a relatively brief child assessment that is conducted by a Head Start teacher or other local Head Start staff member (HHS, 2003 attachment $\mathrm{A}$ ).

The local staff responsible for administering the NRS is required to receive 6-8 hours of training from a trainer who in turn had been 
trained for two and one half-days and certified by HHS trainers (HHS, 2003 attachment C).

Based on the field test of the NRS, the assessment is a one-onone assessment and takes approximately 15 minutes per child. Children demonstrating language proficiency in both English and Spanish will be assessed in both languages lasting for approximately 30 minutes per child over two separate sessions. Finally, the assessments should be done in spaces that were comfortable for the child and assessor and also minimized distractions.

\section{Summary}

In this chapter the researcher presented several studies related to school reform in early childhood education, accountability, and assessment of young children and the Good Start, Grow Smart Early Childhood Initiative on language and literacy development of Head Start students.

The purpose of this study was to investigate and analyze the views of Head Start teachers on the impact of the Good Start, Grow Smart Early Childhood Initiative on accountability for early literacy and language skills of Head Start students.

The focus on Head Start teachers emerged from research conclusions that teachers and other adults play important roles in student performance and achievement during the early years. Furthermore, school reform efforts, which emphasize accountability based on results for student learning, have significant impact on both students and teachers. 
Studies were also presented on Project STEP, an on-going comprehensive professional development for Head Start and child caregivers, and the National Reporting System, a new accountability data base for reporting the progress and achievement of Head Start children in literacy, language, and numeracy. The importance of teacher instructional practices and their effects on early learning of children were discussed.

Literature about the role of early experiences in literacy and language with the emphasis on construction and communication of meaning and the importance of teacher instructional behaviors helped to focus the research questions. Literacy and language learning are social processes, and adults, such as teachers, can provide opportunities for children to use language in a variety of ways. The goal of this present study was to add to the literature on Head Start reform and accountability for language and literacy achievement for Head Start children. 
Chapter 3

Methodology

Introduction and Research Questions

The major goals of the Good Start, Grow Smart Early Childhood Initiative include (1) strengthening Head Start by ensuring that Head Start programs effectively prepare children to meet the standards of learning in early literacy, numeracy and language so that young children are equipped with the skills they need to start school ready to learned, (2) ensure the cognitive development of children in Head Start by assessing the standards of learning in numeracy, language and literacy (3) provide training for Head Start teachers through the Strategic Teacher Education Program (STEP) to ensure that Head Start teachers acquire skills in early language and literacy including phonemic awareness, classroom management, basic materials necessary in the classroom to promote enhanced literacy and learning opportunities for children, (4) provide Head Start teachers with follow-up mentoring and coaching to assist teachers implement teaching strategies and effectively respond to individual students, and (5) improving the partnerships between teachers, parents and all other early childhood caregivers through information and the use of curriculum to help guide children effectively toward successful vocabulary development and literacy (The White House, 2002).

The purpose of this study was to investigate and analyze the views of Head Start teachers on the impact of the Good Start, Grow Smart Early Childhood Initiative on accountability for early literacy and language skills of Head Start Children in a Western Maryland 
community. Head Start teachers' views included their roles as teachers of literacy and language for young children and education. Head Start teachers' actual and possible literacy and language instructional practices with young children were also examined.

The data were collected using the qualitative case study approach. According to Merriam (1988), the aim of the case study approach is to uncover the interaction of significant factors that are characteristic of the phenomenon. This approach allowed for an indepth examination of each participant's responses for literacy and language processes, strategies and skills used by the participant during instruction of young children at Head Start. The case study approach also provided a rich and informative individual profile of each participant. From each profile, unique characteristics of the participant emerged as significant data. Finally, the case study approach was used because it provided holistic descriptions and explanations of the phenomenon.

The research questions posed in this study were Question 1:

What experiences and influences have contributed to Head Start teachers' views of education and of themselves as teachers of young children?

Question 2:

In what ways do Head Start teachers' view the Good Start, Grow Smart Early Childhood Initiative? How is it similar to or different from the current Head Start Program? 


\section{Question 3:}

In what ways do Head Start teachers demonstrate accountability for students' achievement and success in literacy and language learning? Question 4:

What emergent literacy and language experiences do teachers provide for their students?

Question 5:

What changes occurred in Head Start teachers' provision of literacy and language learning experiences for their students because of Project STEP?

\section{Methods of Data Collection}

The interview and questionnaire were employed as the primary methods for the collection of data to address the research questions.

Ethnographic interviews of Head Start teachers were done based on Seidman's (1991), phenomenological interviewing, which provided a structure for the in-depth interviewing of each participant. The interview was conducted with individual teachers for a minimum of one hour each. This method also provided a framework for combining the details of each participant's life history and experiences to generate meaning from each participant's responses. Lastly, this method was chosen because it permitted a richer and more complex picture of the Head Start teacher's viewpoints and perspectives on the Good Start, Grow Smart Early Childhood Initiative and the language and literacy practices of the Head Start teachers with young children.

The questionnaire was chosen because it gave each participant some control of the data collection process. According to Gall, Borg, 
and Gall (1996), participants do fill out the questionnaire at their convenience, answer items in any order, take more than one sitting to complete it, and give unique responses to the same questions. Using Gall et. al. guidelines for designing questionnaire, both close and open formats were used to develop the items. The close form items on the questionnaire allowed the participants to provide only pre-specified responses similar to multiple-choice questions and the open form items allowed the participants to make any responses they wished similar to essay questions. A third questionnaire item used was scaled items. The scaled items provided the researcher some accurate data for assessing the participant's beliefs and opinions about the Good Start, Grow Smart Early Childhood Initiative. These unique responses provided a richer and more complex picture of the Head Start teachers' viewpoints and perspectives on the Good Start, Grow Smart Early Childhood Initiative and the language and literacy practices of the Head Start teachers with young children.

Consequently, based on the National Head Start STEP Teacher's Manual (2002), and the Good Start, Grow Smart Early Childhood Initiative, nine standards of learning or indicators (The White House, 2002), the items on the questionnaire were constructed by the researcher focused on the following areas of training for Head Start teachers and assessment of Head Start students: approaches to teaching strategies and assessment, Head Start teachers' professional development, phonological awareness, written expressions, language development, print and book, read aloud, phonemic awareness, and letter knowledge. Each participant had received a total of 30 hours of STEP training in these areas as well as 
skills and strategies to enhance young children's early language and literacy development.

When each item on the questionnaire was written, it was compared to the relevant area addressed in the National Head Start STEP Teachers' Manual and the nine standards of learning or indicators to ascertain that the item would gather specific data on the mandated requirements of the Good Start, Grow Smart Early Childhood Initiative as well as on the topics covered during STEP training, mentioned above, for early literacy and language development of Head Start students. Furthermore, each item on the questionnaire was focused so that each would provide data for the research questions of this study.

\section{Pilot Study of Interview and Questionnaire Protocol}

To establish the validity of the interview and questionnaire protocol, one public school and three Head Start teachers provided critiques. The Head Start teachers were participants in this study and the lone public school teacher who provided critique was a first grade teacher at a school in the community in which this study was conducted.

The interview and questionnaire protocol provided information that were used to respond to the research questions in this study. Each item on these instruments was written to provide data on a specific research question. Table 1 , in this chapter, shows how the questionnaire and interview items were integrated in order to respond to the research questions. 
A first step was to discuss the interview questions and questionnaire with two Head Start teachers who already had Project STEP training.

A major concern on the interview protocol was that some questions might elicit socially desirable responses from the participants. To address this concern, it was suggested that the interview should begin with more open-ended questions. Three questions on the interview protocol were corrected. One question was reworded so that it was open-ended and the other was reworded to avoid making participants uncomfortable. The third question was reworded so that it was not a leading question. All the questions were then redesigned to be more opened and allow for numerous responses.

Three Head Start teachers completed the questionnaire as a pretest. From this process, three questions on the questionnaire were identified as lacking clarity. Each question was then reworded to elicit authentic responses.

After rewording the questionnaire items, volunteer Head Start center managers who also had STEP training reviewed the completed instrument. Feedback was given on two questions that were worded similarly. Both questions were combined into one to elicit one authentic response.

The pilot study of the research instruments aided in the refinement of the questions in order to avoid leading or uncomfortable questions, to avoid redundant questions and to ensure the clarity of each question. It also helped the researcher to determine issues of concern. 
TABLE I: Shows the integration and relationship between the research questions, the questionnaire, and the interview questions.

\begin{tabular}{|c|c|l|l|}
\hline $\begin{array}{l}\text { Research } \\
\text { Questions }\end{array}$ & $\begin{array}{l}\text { Interview } \\
\text { Questions for } \\
\text { Teachers: item } \\
\text { number. }\end{array}$ & $\begin{array}{l}\text { Interview } \\
\text { Questions for } \\
\text { Administrator: } \\
\text { item number. }\end{array}$ & $\begin{array}{l}\text { Questionnaire } \\
\text { Item/ number. }\end{array}$ \\
\hline 1 & 8,9 & 12,13 & $\begin{array}{l}\text { Part I: } \\
\text { Demographic }\end{array}$ \\
\hline 2 & $1,2,34$ & $1,2,3,4$ & Part IV: $9-10$ \\
\hline 3 & 7 & 6 & $\begin{array}{l}\text { Part II: } 6-10 ; \\
\text { Part III: } 1-10 ; \\
\text { Part IV: } 1-2\end{array}$ \\
\hline 4 & 5,6 & 3 & Part II: $1-5 \mathrm{~A}$ \\
\hline 5 & $10,11,12$ & $5,6,7$ & $\begin{array}{l}\text { Part IV: } 3-8 ; \\
11\end{array}$ \\
\hline
\end{tabular}

\section{Participants}

The participants for this study included five current Head Start teachers who received Project STEP training as mandated by the Good Start, Grow Smart Early Childhood Initiative and one Head Start administrator. Each participant had received a total of 30 hours of STEP training in these topics: best practice, phonological awareness, written expressions, language development, print and book, read aloud, phonemic awareness, and letter knowledge as well as skills and strategies to enhance young children's early language and literacy development and learning. All participants were Caucasian. One of the five participants was a male and the remaining four were females. Each of the five participants volunteered for this study. 
There was a total of six individual Head Start centers within the western Maryland community from which the participants were recruited. One of the six Head Start Centers was an Early Head Start Program located on the same floor and in the same building as one of the other five centers. Teachers from the Early Head Start program and the regular Head Start interacted on a daily basis due to their close proximity to each other and also because they share the same facility.

The participants for this study represented a Head Start administrator from the investigated Head Start program and teachers from all the six Head Start centers serving young preschool aged children and their families in the community. Although some of the participants had been Head Start teachers longer then others, on the average, all the participants had been Head Start teachers for four years. The administrator had been at Head Start for seven years at the time of this study.

The researcher recruited all participants. The researcher initially contacted a senior administrator of the Human Resources Development Center, HRDC, and explained the rationale of the study to the administrator. Following this meeting, the administrator provided the researcher the opportunity to speak to all the teachers of all the Head Start centers in the community at the same time. During the meeting with the teachers, the researcher presented the purpose for the study to the teachers, responded to the teachers' questions about the study and then asked for volunteers to participate in the study.

There were several criteria used for the recruitment of the participants. One criterion for selection of participants was that 
participants should be Head Start teachers for at least two years prior to this study. This criterion was critical because it provided a span of time in which each participant would have been a Head Start teacher before the Good Start, Grow Smart Early Childhood Initiative and would have had time, after the legislative mandate, for each teacher to receive Project STEP training.

The second criterion was that participants should be recruited from all the six Head Start centers present in the western Maryland community. This criterion was necessary for ensuring that the participants would be typical and representative of the investigated Head Start community.

A final criterion was the researcher needed to have a professional collaborative relationship with the participants of the study. For the past four years, early childhood education candidates from a nearby university were placed within various Head Start classrooms at each of the Head Start centers as part of the candidates' required practicum experience. The candidates were students of the researcher. Some of the early childhood candidates were invariably placed in the classrooms of all the participants of this study. The researcher served as the supervisor for all the early childhood education candidates during their practicum at Head Start. Hence, this criterion was necessary because it provided the researcher with a group of participants whose work as Head Start teachers the researcher was professionally familiar with.

Each of the participants in this study met all the criteria for participant selection as explained in the preceding paragraph. 
Finally, to triangulate the Head Start teachers' views on the Good Start, Grow Smart, the researcher also interviewed an administrator of the investigated Head Start program.

\section{Setting}

The interview was conducted in the homes and offices of the participants. Some participants worked during the time of the study and their offices served as the setting for the interview while other participants preferred to be interviewed in their homes. The homes and offices are located in a small city in a rural county in a midAtlantic state.

There was a range of economic difference within the county. While a nearby university employed some residents, most were bluecollar workers of such agencies as the local paper mill, railroad, and hospitals. Even though many people in the area had employment, others were moving to the surrounding states because many local companies had closed in recent years.

\section{Procedures}

The researcher contacted the local Head Start senior administrator in order to inform that agency of the study. The administrator then granted the permission for the researcher to speak to all the Head Start teachers in the community during a previously scheduled staff development workshop. At that meeting, the researcher explained the purpose of the study, the rationale, the procedures, confidentiality of the data, and the potential benefits of the study to all the Head Start teachers. After responding to the 
teachers' questions about the study, ten Head Start teachers volunteered. Five of those who volunteered did not meet all the criteria for participants described in the "Participants" section earlier in this chapter. Five others met all the criteria. The teachers meeting all the criteria became the participants for the study.

The first investigative instrument used with the participants was the questionnaire (see appendix E). The researcher mailed the questionnaire to each participant. Included in each packet of questionnaire was a self-addressed return envelop. Each participant returned the completed questionnaire to the researcher via the mail. Five questionnaire instruments were mailed to the five participants of the study and the researcher received five completed questionnaire instruments from all five participants.

The second investigative instrument used was the interview protocol (see appendices $C \& D$ ). Appointments were made with each participant for the interview. The study was conducted in the homes and offices of the participants. Some participants worked during the time of the study and their offices served as the setting for the interview while other participants preferred to be interviewed in their homes. Four interviews occurred in the offices of the participants and one interview took place in the home of the participant. All interviews were audio taped and averaged at least one hour per interview.

\section{Treatment of the Interview Data from Head Start Teachers}

The data were analyzed according to the phenomenological method of Hycner (1985). This method provided the means through which units of relevant meaning were separately identified, clustered 
according to similar ideas and then grouped into broader themes. This method is commonly used when interviews are conducted in a study. The method allowed the researcher to obtain a clearer description of the participant's views on the Good Start, Grow Smart Early Childhood Initiative.

Each interview was audio taped and transcribed. The tapes were again reviewed in order to detect additional meanings that may be revealed in the teacher's emotional undertones, inflexions and intonations.

From each interview data, units of meaning were identified in order to help describe the teacher's meanings. This involved segmenting the transcripts into units of sentences or phrases, which expressed some unique meaning. Through this process, all the statements from the participants were divided into units of meaning. These units of meaning were pasted onto index cards and the cards were sorted and grouped according to similar or related meanings. Categories were then derived for each grouping.

Group categories were clustered and titled to indicate more general meanings and to relate the meaning units to the research questions. Common themes and natural groupings of the interview data evolved. 
Treatment of the Interview Data from the Head Start Administrator

The administrator's interview was transcribed. Analysis of the interview from the administrator was done with a phenomenological approach similar to the Head Start teachers' data. The interview was separated into units of meanings and categorized.

The information was then studied to determine relationships to the Head Start teachers' data and it was used to assist in further describing the Head Start teachers' views and to triangulate the data from the teachers.

\section{Treatment of the Questionnaire Data}

For the purposes of this study, the analysis of the open format items on the questionnaire were analyzed in identical fashion as the interview data with a phenomenological approach by Hycner (1985), described earlier in this chapter. Each participant's response was separated into units of meanings and categorized.

The information was then studied to determine relationships to each participant's interview data. This process assisted in clarifying and substantiating the participant's data. Also, the open items on the questionnaire were used to further describe each participant's views and experiences as a Head Start Teacher and the Good Start, Grow Smart Early Childhood Initiative.

The close items and scaled items on the questionnaire provided demographic information on each participant and a more accurate assessment of each participant's belief and perceptions about the impact of the Good Start, Grow Smart Early Childhood Initiative. The 
data were used to further understand and ducument each participant's interview data.

Finally, the closed, opened and scaled items provided data that were used to describe each participant's experiences and to triangulate the interview data from each participant.

\section{Summary}

In this chapter, the researcher described the methods of investigation used in this ethnographic study in which the views of Head Start Teachers on the impact of the Good Start, Grow Smart Early Childhood Initiative were examined regarding accountability for language and literacy development for Head Start students. The methods described were, general procedures, setting, the selection of participants, and data analysis. The presentation and interpretation of the data are presented in chapter 4 , and in chapter 5 the implications of the study are discussed. 


\section{Chapter 4}

\section{Interpretation of Data}

This chapter contains a systematic interpretation, or contextualization, of the data for this study. Contextualization attempts to interpret the structures that emerged during the earlier processes of data analysis "and give them meaning by locating those structures back in the natural social world. Contextualization also helps to locate the phenomenon in the personal biographies and social environments of the persons being studied. It presents the phenomenon in their language, in their terms, and in their emotions. It does this through thick descriptions of the phenomenon as it occurs in their world of interaction. The intent of contextualizaton is to show how lived experience alters and shapes the phenomenon being studied" (Denzin, 1989, pp. 60-61). Furthermore, (Denzin, 1989; Stake, 1994), stress that this process allows the investigator to then put forth an inquiry through the interpretative process, not conclusion. The readers, not the researcher, draw ideas or conclusions from the interpretation that resonate to them in relation to their understanding and experience.

Contextualization was focused on the central participants in the study in order to allow their viewpoints to be heard. In this study, the central participants were Head Start teachers and an administrator. Interpretation, being subjective, also involved the investigator. As such, the investigator clearly stated her stance in relation to this study. Hence, in this study, the investigator grew up in Liberia, West Africa, where she earned her undergraduate degree in elementary 
education. She was a schoolteacher in her native Liberia for five years before pursuing graduate schooling. She has lived in western Maryland and worked, through a nearby university, with the Head Start Program for five years at the time of this study. She has always been sensitive to the needs of people in poverty, especially young children. She is an instructor and scholar in early childhood education, searches for harmonious relationships, and is a wife and mother of one child. Her particular interest in relation to this study is in examining the views of Head Start teachers on how the Good Start, Grow Smart Early Childhood Initiative would impact them and their students and how the initiative will help develop their students' language and literacy skills.

Chapter 4 involves a description and interpretation of the views the participants of the study on the Good Start, Grow Smart based on the research questions.

\section{Themes of the Study}

The data analyses yielded seven broad themes, which formed the foundation for the answers to the research questions. The themes were:

1. A personal description of the Head Start teacher.

2. A philosophy of teaching

3. The Head Start teacher's views on the Good Start, Grow Smart.

4. Assessment, Reporting and Accountability.

5. Instructional Practices.

6. The Usefulness of Project STEP.

7. Challenges: The Individualized Education Plan (IEP), Parent Involvement, and Disruptive Student Behaviors. 
Themes 1 and 2 formed the discussion of Research Question 1 . Theme 3 formed the discussion of Research Question 2. Theme 4 applied to the discussion of Research Question 3. Theme 5 formed the discussion of Research Question 4, and theme 6 dealt with the discussion of Research Question 5. Theme 7 emerged as a strong concern of the Head Start teachers but was not included in the original research questions. The data underlying this theme are reported after the discussion of the five research questions.

The research questions that guided this study are now stated followed by discussions based on the data. Pseudo-names have been given to each of the participants for confidentiality purposes.

Research Question 1: What experiences and influences have contributed to Head Start teachers' views of education and of themselves as teachers of young children?

A personal description of the Head Start teacher and Administrator.

Cindy, a woman in her 50's, was medium-height and with silvergray hair. In general demeanor, she appeared pleasant, confident, and business-like. When she talked, her words flowed freely and she was matter-of-fact as if time was meant to be used wisely. Cindy has worked at Head Start for 23 years. She has always wanted to work with children in some capacity and she described her work with Head Start children as "a personal fulfillment". She was the Head Start teacher with the longest tenure in this study.

Patty, an administrator, was in her late 40's. She was married and had worked with the investigated Head Start Program for seven 
years. She had blond hair and was of medium height. She appeared confident and friendly. When she was asked about her work she said "I love my work".

Anne, another participant of this study, was married and had worked at Head Start for two years. She had blond hair and was well spoken with a quiet voice. Anne is in her late 20's and she appeared generally calm, reflective, and alert. While she spoke lovingly of the three and four year old children she taught, with a note of sadness in her voice she, acknowledged, "experiences in the lives of the little ones that can make you cry". Anne, having worked for two years, had the shortest tenure as a Head Start teacher in this study.

Mike, the only current male Head Start teacher, had worked with Head Start for two-and-a-half years. He was not married at the time of this study. In his 30's, with brown hair and compactly built, Mike spoke in a resonating voice. He had a good sense of humor as if to mean that although life was serious, laughter was even better. He appeared energetic and optimistic about the abilities of the three, four and five year old children he taught saying "I think sometimes, we don't push the kids as high as we could because I think there are kids who could do a lot more".

Amy, a tall blond-hair, and slender woman, was in her early 30's and had worked with Head Start as a teacher for the past two-and-ahalf years. Her tone of voice was soft but she was also well spoken. In general demeanor, Amy appeared calm, analytical, thoughtful and precise about what she said. She was selective with her choice of words so that the words used conveyed clear and specific meanings. 
Debra, a married mother with three children, was medium height with dark brown hair. She appeared friendly, thoughtful and alert. Debra was well spoken and as she talked with the investigator, her words seemed to flow freely. She had worked at Head Start for seven years and during the last year, she'd worked with three and four year old children. With seven years of work, Debra was second to Cindy relative to tenure as a Head Start teacher in this study.

Educational and Career Background. After her graduation from high school, Cindy took some time off, got married and became a housewife. Later when she began her career at Head Start, she was able to enroll at a local community college and earned her CDA (Child Development Associate) credentials and an Associate of Arts (AA) degree from Human Services in mental health. At the time of this study, she had enrolled at a nearby college in pursuit of her baccalaureate degree. Cindy believed that her education had enabled her professionally and in her interactions with other people. For example, she said: "taking classes reinforce things that I do in the classroom and I am not afraid to go beyond". I will not just do something because someone says so, I need to understand why."

Cindy first heard about Head Start from a Head Start employee. At that time, Cindy was at high school and wasn't thinking about a career outside of the home. Her goal was "to get married and have a large home". While she was studying for her degree in Human Services, she did some research on Head Start and decided, "this is where I want to work". With the support of her husband, she began 
her career with Head Start, which she says has been very rewarding to her personally.

Patty has not always been an educator. She said, "I had been in management before in different places including stores". While Patty found her college education to be meaningful, she however felt that the education she received hadn't prepared her well for the job she does now. For example, she said, "If I look back now based on the job that I do now and the new research dealing with \{children\} ages birth to five, I don't think that I was prepared well enough to be able to work in a preschool. I don't think they \{college\} offered enough courses or enough experiences in children from birth to age five." She did not even want to work with preschool children. She noted, "its funny now. I wanted nothing to do with kindergarten or below kindergarten. I wanted to be a third grade teacher. I wanted nothing to do with the little ones and \{now\}, I wouldn't leave my job for anything, I love it."

After Patty earned her undergraduate degree in education, she applied for a position as teacher with Head Start. However, she did not know what Head Start was. Accordingly, she said, "I did not even know the program existed until I had an interview. Once I got into the program and started working as a teacher, I fell in love with just being able to individualize \{instruction\} for the children and actually watching them grow. Being able to plan and implement my own curriculum, that wasn't just some piece of paper that someone else somewhere told me I had to teach, was great. That's why I stuck around. I was a teacher for about two years. Then I became a center manager in charge of three outlying centers. I moved into the Assistant Manager's position implementing the Early Head Start Program. I have been an 
administrator for seven years." At the time of this study, Patty was one of the senior administrators at the Head Start Program investigated in this study.

Unlike Cindy, Anne went on to college following her graduation from high school. She earned her baccalaureate degree in early childhood/elementary education from a nearby university. After graduating from college, Anne worked as a substitute teacher until she began her full-time work with Head Start.

Anne had always wanted to work with young children, especially pre-school or kindergarten children. While she reflected on some of the difficulties experienced by some of her students she sounded hopeful and proud of the impact the Head Start experience had on all the children. According to Anne, "the wonderful thing about Head Start is that we give them \{students a lot of reinforcement, a lot of positive attitude toward learning. They seem so excited to come to school every day and hopefully we will keep that idea going throughout elementary school."

As the lone male teacher and participant in this study, Mike, like Anne, continued his college education immediately following his high school graduation. He described his high school experience as "a haze" because he couldn't make up his mind about what he wanted to do. Even during those indecisive years, he said, "I always wanted to teach. I transferred to college, got a little more serious and a little older, I started thinking-I like kids and they seem to like me." He was the only male in his early childhood classes at college, a realization that led him to believe that “there probably aren't many males that like to do this job so that's even a plus to get a job. I'm glad I did". Other 
experiences Mike had during his college years included teaching a remedial math course and also tutoring some elementary math majors. Mike graduated with a baccalaureate degree in early childhood education but did not immediately get a teaching job. After a period of five years in which he held many different jobs outside his field of study, he applied for a teaching job and was hired as a teacher at Head Start.

When Amy graduated from high school, she attended a community college. She got married during those years and with the support of her family, transferred to a nearby university from which she earned her baccalaureate degree in early childhood education.

Amy did not always want to be a teacher. In fact she said "when I was in high school, if someone had told me I would be a teacher, I would have laughed in their faces. There was no way." However, as the years went by and she got older, the thought of being a teacher didn't appear so questionable. Thus, when she learned about a job opening at a local Head Start, she applied for the job. She was hired as a child behavior specialist and worked with children who had behavior, emotional or physical problems on a one-on-one basis. This experience was the career turning point for Amy. When she spoke of this event Amy said, "once I started here, I really got an eye opener about how miraculous it is to see the children learn and to see them grow. J ust the feeling of helping all of the kids was really amazing to me. So much so that when I graduated with my teaching degree, I knew that this was what I wanted to come back to."

When reflecting on her career and educational path, Debra remember many anecdotes. She had one major goal for herself during 
much of her childhood and this goal remained the same throughout her high school years. As she talked about this goal she said, "I never actually thought about being a teacher. I can remember in second grade when the teacher asked 'what do you want to be when you grow up' and I said I want to be a mom. That's all I ever wanted to be and my goal was to get married and have kids." Debra eventually realized her goal immediately following her graduation from high school and had three children. She was divorced from her first husband and subsequently had to find work outside of her home. It was during the years after she had remarried that she constantly talked about becoming a teacher and her second husband was very supportive of her. She recalled that he said, "if that's what you want to do, just go and do it. He put me through school which I thought was very nice of him." This, according to Debra, was how she earned her baccalaureate degree in education and became a teacher.

Following her graduation from college, Debra worked as a substitute teacher until she was encouraged by a friend to also add her name to the Head Start substitute list. Debra did and according to her, "when I went there $\{$ Head Start\}, it was a lot less money than anywhere else, but I fell in love and had much more enjoyment there making much less money than anywhere else". Therefore, when a teaching position became available, Debra applied for that position and was hired as a Head Start teacher. That was seven years ago and she continued to enjoy her work currently.

Educational Influences. When Cindy was a child, her mother and father had to work outside of the home, and her aunt took on the role 
of caregiver and teacher because, according to her, "in those days they didn't have kindergarten and all the pre-schools in the area were privately run and expensive; so I didn't go". As Cindy spoke of her aunt and the time they spent together, her words flowed freely, her face appeared to gleam, and time stood still. In this posture, she said, “My aunt didn't go more than ninth or tenth grade, but she had the natural ability of a teacher, and she would sit and work with me. She used candies, M\&Ms, and from that I learned sequence, and how to sort. From the coloring books, I learned my colors. She always read books to me and we did a lot of phonics. I knew all those things before I started school." She finally added, "You see, just having someone there can make a big difference."

Patty's influences had come primarily from her roles as a classroom teacher and an administrator at Head Start. Her earlier influences came from her teachers. Patty believed that the teachers who influenced her the most were her third and fourth grade teachers. When she spoke of these teachers, she said, "I can remember having an absolutely wonderful teacher in third grade and then also in fourth grade who actually paid attention to me and knew about me. They cared about me. In college it was okay. It was very impersonal. There was a whole bunch of us and people didn't know our names."

During her tenure as a teacher, Patty's ability to work with individual students influenced her greatly. She recalled a little girl who had some problems and needed help. "I remember a little girl who had something wrong with her. She had scars all over her face, she was very shy, and wouldn't open up to anyone. I was able to develop a relationship with this three year old child that allowed us to find out 
she was an abused child. J ust being able to help get her into medical testing, being close so that a three year old trusts you to let you know the problem was something I'll never forget. That was seven years ago." Another significant experience was Patty's transition from being a teacher to being an administrator. Although Patty loved her job as an administrator, she said, "I was one of them \{teachers\} and all of a sudden, I'm the big bad management person. It has taken me a very long time to learn how to deal with adults rather than kids and to earn their \{teachers\} respect."

Anne had also been enabled by education but in a different way. While she fondly remembered her childhood spent with caring parents, she said, "My schooling taught me the main idea-what to do in the classroom. Essentially, my internship taught me more than anything else. I was with teachers who taught me basic classroom management. I had time with the children and that makes you a better teacher."

In a similar situation like Cindy, Mike's most significant educational influence came from a family member during his childhood. Speaking of that early childhood experience and in a fleeting but pensive moment, Mike recalled his grandmother and what they did together. He said, “My grandma, she's my first teacher. She's the one who taught me to read. She had 12 books and they were the same books all the time; she would point at the words as she read. Since they were the same books, I knew all the stories. I got to sit on her lap and did the same things over and over - like how letters sound. I just picked up the words. It worked for me and that's why I like phonics."

Another early experience Mike recalled that influenced him was with his first grade teacher. He said that the one activity he never 
liked as a child was art and he ran and hid in the teepee-like structure that was in his classroom whenever it was time for art. He said, "I hate art. I wasn't good at it and I hate it and to this day will prefer somebody else to handle it." Then came his first grade teacher "Ms Sherry' who made him feel better about his work. Thinking of one experience Mike said, "She was awesome. She saw my artwork and I thought I was going to get in trouble, but she said, 'Oh this is so beautiful' and I will never forget that moment. I got straight A's in her class and that's the only time I've ever done that."

Amy said that her education had enabled her to work with other adults and also in her instructional practices with young children. Formal schooling provided her a lot of valuable information about how young children learn and develop. Amy stressed the significant role her internship played in shaping how she approached her tasks in the classroom. She said it was a wealth of learning experiences because "seeing how other teachers approached young children's growth and development and practicing how to screen a real-life child were invaluable." When commenting on her education Amy said "I can go back in my mind and find what a child can do at what age and have a general feel for the child educationally". Amy narrated an event that appeared to illustrate how she initially assesses a child. She said: "I had a boy in my class. When I did the home visits, his parents told me that he was intelligent, wonderful, can talk a lot, and he was right where he should be. When the boy came to my class, he wasn't even there for two hours and I knew something wasn't right. For example, he couldn't sit down. One adult had to stand at the door to physically keep him in the room because he was constantly trying to run out of 
the room. After a lot of discussions with the parents, they agreed and the boy was tested. We found out that the child was autistic." Amy added that while it was a difficult decision for the parent, one child in need got the help he needed.

Finally, while Debra believed that her schooling had a significant impact on her, including her internship, she believed her children influenced her the most relative to how she approached her role and tasks as a teacher. She interacted with her children in different ways. For example she "read to them, sang songs with them, played games with them and even planned picnics with them in their backyard." She smilingly added, "I enjoyed them so much. It was after I had them that I said 'hey, I want to be a teacher'."

Another event that influenced Debra occurred when she was in the sixth grade. There was a kindergarten teacher who allowed some elementary school students in her class as helpers. Debra remembered how joyous she felt when "Mrs. Wilkins" chose her to help in the kindergarten classroom and said, "Some of what I do with my students come from being in that kindergarten classroom."

A Philosophy of Teaching. Cindy believed that research was critical for understanding the "reason behind what you do". She feels that every person needs the time to find out why some things work and others don't. For example, music is an important part in the classroom for listening and movement activities but "from research, I found that loud music can be very distracting for children with fetal alcohol syndrome, but rhyming words works for them. That is what research does for me." Furthermore, she believed that young children 
can be taught a lot of skills but those children will "remember for a long time the activities that were repetitive, activities that they enjoyed and were related to their lives, activities that are interesting because it makes them think more, and activities in which the teacher, parent or adult worked one-on-one with the child and praised the child for whatever they can do".

Patty believed that individualizing instruction for children was a critical component during teaching. She also believed that the adults who demonstrated care and who were concerned about the well being of the children in care provided those children with a good foundation for the social-emotional development for those children. Her experiences as an administrator had provided her with a framework for understanding Head Start teachers' concerns. Speaking about this, Patty said, "I can really make a difference in the way that teachers are treated, the way they are respected, and that in turn will help the Program \{Head Start $\}$ and help the kids".

Anne approached her role and tasks in the classroom with some basic goals and beliefs that were significant to her. When teaching, Anne's goal was "to treat each child individually because each child is an individual. That's what they need." She believed that Head Start provided a unique context in which the individual nature of the child was recognized and respected. Also, she believed that when a child was respected, that child learns better because "planned activities involved the interests of the child". Thus, she added, "the great part of the Head Start program is that we are able to teach each child on the level they need". 
From his college experiences involving tutoring and his present work with young children, Mike said that he had learned that there is not much difference in teaching people who need help regardless of their ages. He said that while developmental differences existed and were critical for children, when it came to teaching an adult who had a subject-related problem, for example, the strategy was the same you would employ for a young child in order to help that adult understand and learn. Speaking of this Mike said, "In some ways, teaching adults can be more difficult than teaching children. You have to go back to basics and go step-by-step. With kids you have to do that a lot." Nonetheless, for instruction to be effective for children, Mike believed that the teacher-student interaction was critical. To that end he said "I love the one-on-one with kids. You get a lot done that way."

Amy's beliefs about children and how they learn appeared to be based on the knowledge she acquired during her college education. She believed that all children could learn when given the opportunity to do so. She believed that Head start "is just such a great place for providing the opportunity for low-income children". Furthermore, she believed that the teacher's knowledge of young children's growth and development were critical to what is taught and learned by children in the classroom. In fact "Teachers are great models for the students."

Debra's beliefs appeared to have come from her personal life stories, especially her children and her childhood experiences. During her childhood years, she was "extremely shy" to the point where she hid behind her mother if someone just walked up to speak with her mother. For this reason, Debra said, "I can relate well to the kids in my classroom who are shy. If I had someone who made me do it, I 
would have had lots of fun but I was on my own - I would never do anything. So I try to push the shy children just a little but I don't want them to be afraid and at the same time I don't want them to be alone. I know that feeling." She believed, therefore, that "young children are funny, serious, honest, they can pick things up easily by watching others and imitating others, interesting, and can be easily excited when engaged in authentic hands-on activities."

Summary. Beginning early in their lives, competent adults influenced all the Head Start teachers and administrator in this study. Those adults, whether they were family members or teachers, had similar characteristics and qualities. According to Cindy, Patty, Mike, Amy, Debra, and Anne, the adults who had influenced them the most were caring, consistent, dependable, exciting, always treated them as individuals, fun, respectful, patient and always positively reinforced their efforts. Those adults were role models that the Head Start teachers remembered. While Debra's children brought her much joy, it seemed to be in her role as the adult that she exhibited some of the qualities she had enjoyed from other adults during her childhood. It seemed then, that each Head Start teacher's personal life experiences and education significantly influenced their philosophy and orientation towards young children.

Research Question 2: In what ways do Head Start teachers view the Good Start Grow Smart Early Childhood Initiative? How is it similar to or different from the current Head Start Program? 
The Head Start Teacher's and Administrator's Views on the Good Start, Grow Smart.

The data dealing with this theme will be presented in four categories (1) general impact, (2) strengthening Head Start, partnering with states to improve early childhood education, and (4) providing information to teachers, caregivers, and parents.

General Impact. Cindy described her understanding of the requirements of the Good Start Grow Smart, her preparedness to implement the requirements, and her knowledge base of the initiative as "excellent". She eloquently explained that the initiative was "to promote literacy, pre-reading, and the other skills for children at an earlier age even at Early Head Start, and later it's going to include children working on math skills. I am an avid reader and I believe literacy is very important." Between the current Head Start program and the good Start, Grow Smart, Cindy said that she didn't see much difference except the "push on the language and literacy. They are not taking anything away, just adding on in some ways." She added, "I think we've always been reading to the children, but we're now defining what we've been doing for years. As a person, it stimulated me thinking. I think in abstract ways now than I did before, like I'm relearning patterns. It has made me more aware of what I am doing and why I am doing it." Cindy acknowledged that the initiative was going to bring on some level of change but "when you work for the government, they change things; they change the paperwork every couple of years. Since l've been here, they've changed the screen 
about five times. But that's good because it shows the growth and aiming for another direction."

When describing her understanding of the Good Start, Grow Smart Early Childhood Initiative, Patty said, "I'm interested in it's implications to Head Start Bureau and what they \{policy makers\} are forcing our program to do. The push is on language and literacy and they are basically ignoring the rest of our program. They are saying you are basically doing nothing. That's how I feel. I think some of the ideas behind what they want are good but the way they are going about it is not good."

Anne, on the other hand, described her understanding of the requirements of the Good Start Grow Smart, her preparedness to implement the requirements, and her knowledge base of the initiative as "minimal". Although she had read the Good Start, Grow Smart document, she said, "I'm not very sure about all of it". However, when Anne spoke about her understanding of the initiative, she said, "I see it as what we are doing right now in Head Start. It is a way to make Head Start accountable for what they are doing. It's just a way to make students prepared for school, for kindergarten, and make states integrate what they have already done." Anne spoke similarly like Cindy about the similarities and differences between the current Head Start program and the Good Start, Grow Smart. She didn't see much difference except that the initiative "emphasized the language and literacy skills, but everything else remained the same in Head Start."

Mike described his understanding of the requirements of the Good Start Grow Smart, his preparedness to implement the requirements, and his knowledge base of the initiative as "good". As 
Mike talked about his general views about the Good Start, Grow Smart, he had more questions and concerns than answers. He said, "I haven't heard a lot about it other than it's another change. Every year that I've worked here, they've changed something. It's going to be a more literacy-based system and I actually think that's good. But what is this going to do? You know, what will it mean for us here? That is what bothers me."

Amy, another Head Start teacher and participant of this study, described her understanding of the requirements of the Good Start Grow Smart, her preparedness to implement the requirements, and her knowledge base of the initiative as "good". Furthermore, she understood that "the goal of this policy is to increase early childhood learning. All programs will be responsible for assessing their children so that all the children receive the same level of education." She explained that the initiative "reinforces what I am already doing and reminds me that I have to do more literacy and language in the classroom and I think it will be determining what kind of teacher I am."

Finally, Debra described her understanding of the requirements of the Good Start Grow Smart, her preparedness to implement the requirements, and her knowledge base of the initiative as "good". Expanding on her understanding, Debra said, "The initiative is really to have children ready to start kindergarten with their language and literacy skills. I think it's a good program from what I know because I do think the children need the literacy skills, like the phonemic awareness and all that once they get to school, but they are adding a lot of things to our program. Maybe the new teachers will not feel that these are new and a lot more work because that's all they know, but it 
is for those of us who have been here longer. I do feel that we have done these all along but the big difference now is the push on language and literacy rather than the socialization. Well, I think the initiative will better the program. I think it is good." While adding more to the Head Start program inevitably means "more work" to be done, Debra said, "I am excited about exploring new ways to use books in the classroom with the children. I don't think there is anything that we used to have in our program that we don't have, it's just been added to."

Strengthening Head Start. When Cindy spoke specifically about the requirements to strengthen Head Start, she said, "I think it's wonderful. I wish we had done this a long time ago. We should have kept up with foreign countries whose children speak more than one language. They start education with them a lot sooner, and they do a lot of pre-reading and writing skills. In our country, it seemed like for a while, reading was a lost art."

Patty also said that strengthening Head Start was good. However, she didn't seem very positive about the level of training provided by STEP. She noted this by saying " They \{policy makers need to look at individual programs and decide what areas need what. I don't appreciate being forced into training I don't need. I know the teachers don't appreciate it."

Anne agreed there was a need to have more language and literacy in the classroom and said, "We need to be accountable for that." However, she wanted to be able to adapt strategies that are suitable for the three and four year old children in her class because "they are young and they need time to adjust". Anne explained that 
"although I am still using language and literacy, in the first part of the year, I'm focused on social skills development- sitting down, having conversations and discussions about how to behave, how to take turns and how to just get ready for learning and adapt to the class. I do a lot of modeling. When the children are used to and familiar with these then we move on. In the second half of the year, the children can have academic instruction you know, more educational, but it's not the type of education that they want us to do that I do in the first part of the year."

Mike thought that having the literacy and language focus was actually good for Head Start because, as he put it, "I am already doing those things they're asking anyway with literacy, with words and with phonics. "I only see for my students-what's best for them. I can only take them from here and get them there. For some of them, they don't know how to write, only scribble and that's okay." As he continued talking about how to strengthen Head Start nationally, he appeared to lose some of his optimism. He said, "I have to look at things myself and make a final judgment, and right now I don't think I know a lot about it \{the initiative to say it's good or bad. I won't say it's taking us to a train wreck as everybody wants to make it out to be."

Amy thought the initiative's goals for strengthening Head Start was good because, hopefully, having the same assessments will ensure that all the children would receive the same level of education. She was interested in knowing how the assessment data would be used. For example, she said, "I find it interesting that the assessment is the same for all of the students. What about the children who have 
individualized education plans (IEP)?" The issue of the IEP will be presented later in this chapter after the data related to the research questions are given.

Debra said she felt good about strengthening Head Start primarily because she was prepared to do so by the local Head Start Managers. She said that the managers did not wait until the last minute to inform them about what they should be doing. She said, "I feel our managers looked down the road and saw what was coming and prepared us."

Partnering with States to Improve Early Childhood Education.

Cindy described her understanding of this partnership as "good". She did not sound convinced about this requirement when she said, "Head Start has done such a good job with the physical and nutritional needs of the child, keep that up." However, she was concerned about the level of politics involved and expressed this saying "the President is on one side and the public school and the Board of Education (BOE) on the other side, and they are saying why have two standards. The BOE already have preschool, why not put the funds into that. I think the president is on the fence right now because he says there are Head Start teachers who work with low-income children, and they need training." This national debate appeared to be creating a level of concern. According to Cindy, "I like to know exactly what is going to happen because it affects me, my job, and how I spend the rest of my working life. I think if we go through the $\mathrm{BOE}$, I will be like an instructional aide because I don't have my four-year degree. That's no problem, I'll do what I have to do to keep what I love doing, you know." 
Patty, the administrator, was also concerned about the nature of the partnership with the state. She was unsure of the impact the state would have on Head Start funding and the education of Head Start children. Concerning funding she added, “keep me current on all the new trends but don't take away my funding." She was also concerned with how educational information would be shared between Head Start and the state. She expressed this concern when she said "BOE \{Board of Education\} is completely off the page on how to educate very young children. I don't want them $\{B O E\}$ to say to me 'here's how it should be' and we \{Head Start \} will be like them. I don't want that at all."

Anne was animated when she spoke about the partnering with the states to improve Head Start but again she expressed some concerns when she said, "The thing that particularly interests me is the funding. The way it seems is they want to integrate all the funding in all the pre-kindergarten programs that they \{public school\} already have, and all the Head Start funds will be added into that. In theory, it sounds good, but in practice, I don't think it will be good because the Head Start children will not be getting the same experiences they are getting now. For example, Head Start embraces the families of the children very well. I don't see how the pre-kindergarten programs work with children in the same aspects that Head Start does. So, that concerns me."

Mike was also very interested in this part of the Good Start, Grow Smart. He too, sounded concerned about how funds would be used by the states. In expressing his views, Mike said, "Are they going to fund this initiative or is it going to be like one of these things where 
there is like not enough money in the budget? It seems like-you knowthe funds will be grant money and you can play with it. What exactly will happen- I really don't know."

In the area of partnering with the states to improve Head Start Amy said, "I think that if we \{teachers\} will be held accountable, it is good that they are giving us the training as part of this partnership to help the teachers who need the extra help for understanding the language and literacy and how to incorporate them in teaching the children." However, she expressed concerns with the proposed use of funds for the initiative. Thus, she added, "the thing that worries me is our funds will go through the Board of Education (BOE), and the BOE could change Head Start from what Head Start was originally created as - to help low-income children and their parents. I feel they'll still help the children but will lose that critical part of helping the families as well."

J ust like the other Head Start teachers in this study, Debra had concerns about the partnership with the states and what it meant. She said "I think our program is working well, but if the state takes over, what's going to happen to our program? I don't really know. The politicians are saying that Head Start isn't doing what it's supposed to be doing in language and that sounds good if you don't know Head Start. However, what they are saying we should do just went into effect in the last year and so how can we have improvement on something when the results aren't even in from the way the program is working now? But they make it sound like all along, this had not worked when it only started last year. That upsets me. It worries me. What's going to happen to Head Start if the state takes over? Will there only 
be a four-year-old and not a three-year-old program - who knows? I think a lot of the parent part of the Head Start program will be missing, and I feel that is a very important part."

Providing Information to Teachers, Caregivers, and Parents.

Cindy also described her understanding of this part of the Good Start, Grow Smart as "good because we are all working for the child in that way". She acknowledged that "parents are the child's first teachers, and I think sometimes, we forget that. I think we need to be respectful and include, to a point, what we can of their home, their thought, and their culture." However, Cindy said that involving parents was a challenge. This topic was part of a theme that emerged from the data but was not part of the original research questions and will be presented after the data related to the research questions.

Patty thought that this part of the initiative was a positive step toward improving preschool education because parents, administrators, teachers, and caregivers were all critical components in the education of young children.

Anne expressed support for sharing information because "it is very important to have a family connection and the family is the most important part of the child's life. If the parents are having a happy home life and are stable in their homes, then they are able to give that attention to their children that the children need."

Mike's views on this part of the Good Start, Grow Smart was supportive, like Cindy and Anne. "I think that's great that we will all be doing this. I think there needs to be communication, especially between the parents and the teachers so that we all know what's happening." 
Again, parental involvement will be discussed later in this chapter as a theme following the data related to the research questions.

Amy expressed support for sharing information between early childhood educators, teachers and parents. Since parents are the critical link between the teacher and the child, Anne thought that "the initiative will help us work better together in the interest of the child".

Debra also expressed her support for sharing information between all early childhood teachers, parents and caregivers. She said "I would like to see more adult literacy - like a book club - for the parents because parents are an important part of Head Start." Parent involvement will be discussed later in this chapter after the data related to the original research questions are presented.

Summary. All the participants seemed to have mixed views of the Good Start, Grow Smart Early Childhood Initiative. First, all the participants said that the initiative was a change. Secondly, they all said that the change brought on by the initiative was only "adding to the current Head Start program and not taking anything away from the current Head Start program."

Thirdly, all the participants seemed to support the emphasis on language and literacy skills development in Head Start. Fourth, all the participants appeared to support the training of Head Start teachers in early literacy. However, the areas of need, the level, and type of training needed by the teachers seemed to vary. Cindy said that the topics covered during training provided her with much needed and appropriate information. On the other hand, Amy and Anne viewed the information as information they already knew due to their college 
education. Thus, both Amy and Anne said the training was a revision and a reminder of instructional strategies they had already learned. Patty seemed to believe that specific head Start Program staff may need training based on specific needs. Therefore, she said the policy makers needed to consider such an issue.

Fifth, all the participants appeared to support sharing information between teachers, caregivers, and parents, the third major area of the initiative. The participants seemed to differ in their views on partnering with states to improve early childhood education, the second major area of the initiative, for different reasons. Different views were expressed on funding, politics, and accountability.

Research Question 3. In what ways do Head Start teachers demonstrate accountability for students' achievement and success in learning literacy and language skills?

Assessment and accountability. Since most of the participants of this study were Head Start teachers and were required to complete identical assessment instruments with their students, the data for this theme were presented with each participant's comments following the theme. The data on the role of the administrator in the assessment and accountability of students and teachers were presented following the teachers' data.

Cindy assessed her students and kept a record of each assessment as part of her responsibilities as a teacher at Head Start. Accordingly, Cindy said, "First, we keep a formal written observation record on three different children each day. This is a requirement. 
Since, there are two teachers in the classroom, a total of six formal observations are done each day. We observe and take notes on the child during small and large group activities, and during center. You know, it's a lot of work because we have to include all the areas on the report card. We observe them and take notes during activities, such as math, language, literacy, science, creative arts, social-emotional development, approaches to learning and physical/health development."

In order to document and be able to show each student's progress and achievement, Debra said, "We also keep samples of each student's work in a portfolio. It's neat because you can see what the kid had done over time. Then we have to do the report card. All the standards of learning are included on the report card. The report card is done at the beginning, middle, and end of the school year."

According to Amy, "at the beginning of the year, the report card information is used as a baseline data for each child; the mid-year assessment is used to show the progress of the student, and an end of the year report card documenting the achievement and accomplishments of the student." J im added, "We share the report card data with the parents -you know - during conference time. There's a place on the report card where they can write their comments too."

Adding to how teachers account for the standards of learning, Anne said, "Since language and literacy skills are being pushed, we assess the student's progress and achievement of the standards of learning in language and literacy on a daily basis through observation and the student's work samples. We also screen each student at the 
beginning and at the end of the school using First Step, a developmental screen."

While all the participants in this study were required to complete the same assessments for their students, and they all did, each participant employed a slightly different strategy based on the needs of their students.

According to Cindy, "You have to take the child from where he or she is and help them grow. It's individualized; it depends on the child's individual needs, what they can and cannot do. In addition to the standards of learning, the children need to learn their names, their addresses, count to at least 20 , recognize the letters of the alphabet and be able to begin printing. Those are the skills I think the child should know when he or she is beginning kindergarten."

Anne said that being accountable meant that she must always consider the individual needs of her students. "If a child comes to school in diapers and becomes potty trained by the end of the year, that was my goal for that child. Another child may not be able to identify fifteen letters of the alphabet, but he/she can play with another child without spitting or hitting; that was my goal for that child. It's not fair to expect that all three-year-old children, for example, should be able to do the same exact thing at the same time because each is an individual with different needs, and I will treat each child individually. It's really not fair to all children."

J im considered himself accountable when he also considered the needs of his students and completing all the "required paperwork". He also said, "I think we need to focus a little more on letter recognition, 
speech, and phonics to get children ready to begin school. I have noticed that children who are behind usually have speech problems."

Amy believed she was accountable when required expectations were specified. She said, "I need to know what is expected from my students. If I know the guidelines then I can incorporate what is expected into my daily planning for the students. I will also need specific training so that I know what to do and how to do it. That way, I can prepare them."

Debra, like other participants in this study believed that there was a new push, and in the past, the socialization of the students was the push. She thought that this new emphasis, although not bad, will bring about some changes in what she does in her classroom. According to Debra, the push on language and literacy in Head Start made her realized that it was important that she implemented them in her classroom. As she pointed out, "Now they \{Head Start managers\} want to come in your classroom and see that we are using language and literacy skills. Before, that was never pushed in our classroom. You didn't have to show that you had done it. Now you have to show that it's been done in the classroom."

However, Debra saw some positive aspects about the emphasis on assessment, and she pointed this out. "I think portfolios are amazing. Sometimes you feel you aren't accomplishing anything and then you look in the portfolio and you say, wait a minute they really did come a long way even if it isn't as far as you'd hoped." She explained that the portfolio was significant because it provided data on individual children and the process of assessment, it was better to think of the child individually. For this reason, Debra said "All the children have 
different abilities and you have to work with them from where they are. I believe that while it is necessary to include the standards of learning in language and literacy regularly in class, children need to be potty trained, recognize all of the letters of the alphabet, even if they can't write all, know their addresses, recognize their names, even if they can't write it, and have some abilities with holding a pencil. By that I mean, have developed some fine motor skills." These skills, Debra said are "skills the children need to begin school".

As an administrator, Patty viewed her role as a supportive one to the teachers in documenting accountability for Head Start students language and literacy skills learning. As such, she mentored, monitored, and provided resources for the teachers' use with the students. For example, she said, "I meet weekly with the on-site mentors, and I visit every center each week to discuss educational matters. If a teacher is having difficulties such as classroom management, we take away some of his/her responsibilities so that the teacher has more time to work on the area of need and get the class under control. I have a newsletter that goes to each teacher and in it, I write the theme or skill to be studied in each class. The teachers know what to focus on during instruction from this process. Finally, to ensure, that our internal record keeping method runs smoothly, each teacher sends the students progress and achievement reports to me for analysis. I share with each teacher the results from the analysis of the data. When the data was analyzed for this year, we noticed our math skills had gone down or stayed the same. What happened was that they \{teachers \} were so focused on language and 
literacy they forgot about math. We purchased math computer games and math scores rose so much. So, I see myself in a supportive role."

Summary, It seemed that all the Head Start teachers understood that they were accountable for their students' achievement and success in learning literacy and language skills. They also understood the role of the administrator in ensuring that this process was operational.

All the teachers kept a formal written observation on individual students during small and large group activities including language, literacy, math, science, creative arts, social-emotional development, and physical/health development. Other documentations of the teachers' accountability for students' progress and achievement were individual student portfolio containing student work samples, and a report card that assessed the student on all the nine standards of learning.

The Head Start teachers used varied strategies to demonstrate accountability for students' achievement and success in learning literacy and language skills. Anne used play as a medium for instruction. During play, she modeled language and literacy for and with the students. Cindy would scaffold the skills and Amy relied on the integration of the required skills throughout the daily routine of the classroom. Mike focused on relating the classroom experiences to the real life experiences of the children such as using the names of the students to teach letter recognition.

Finally, while all the teachers expressed that they had each included language and literacy skills in learning experiences for the 
students in the past, demonstrating accountability for students' achievement and success in learning language and literacy skills was a new requirement each teacher had to document in the daily lesson plan for the students. In the words of Debra, "now they \{Mentor-Coaches\} want to come in your classroom and see that we are using language and literacy skills. Before, it was never pushed. You didn't have to show that you had done it. Now, you have to show that it's been done in the classroom."

Research Question 4. What emergent literacy and language experiences do teachers provide for their students?

Instructional Methods and Practices.

Cindy employed different strategies and methods to help her students learn the literacy and language skills found in the standards of learning. She began by arranging her classroom so that it reinforced the literacy skills the students learn and also teach the children, even when she wasn't present. That is, she wanted the students to learn on their own.

Cindy used themes to plan literacy experiences for the students. During planning, she selected books related to the theme and about three vocabulary words from each book. She also had a designated area in the classroom to display the vocabulary words for the students to constantly see. "This is the word wall and beside each displayed word is a corresponding icon, a picture label, to help the children visualize and recognize the word." Cindy demonstrated or modeled 
the concept and introduced the vocabulary during large-group time and then worked in small groups with the children.

Other daily literacy experiences in Cindy's classroom included read aloud, phonemic awareness, writing, and letter recognition. When describing a daily process for developing her students' skills in literacy and language, Cindy said, "I model a lot for the children and ask them to repeat what I say. I encourage them to talk about the theme by asking them open-ended questions about the theme. Then I print the letters in the word/s they say in big letters on strips of writing paper for all of them to see. This helps them to see that what they say can be printed as words, and that's a way to begin making connections between the printed word and what is said."

In other words, Cindy had goals for her students in language and literacy. She pointed this out by saying, "I want the children to see that letters stand for something, the letters put together make a word, the way the word is printed, the print goes from left to right when you read it. Also, I want them to know their thoughts mean something. They can see that we can write their thoughts down. Such as when they say a sentence to me and I write what they say in a sentence. A sentence means something. I want them to know that when they say something, it is their thought, and the sentence is their thought in print."

For Anne, developing the students' literacy and language skills began much like Cindy. She created an environment that reinforced the language and literacy skills learned. Recognizing that children are active learners, Anne planned and created activities in which the children led discussions and conversations. Other activities were 
interactive, such as storytelling using the felt board, and cut-out felt board characters, songs and finger plays, shared reading, rhyming words, and repeating sentences correctly with children.

To describe her methods and processes for teaching literacy and language skills Anne said "At the beginning of the year, I focused on their names to see what common phonemes were there, and I modeled them for the students. I modeled and printed the words to familiar songs, such as Hickory Dickory Dock on chart paper with the students and pointed to the words as we sang the song, and displayed the printed song in the classroom for the students to constantly see the printed words of the song, and I encouraged a lot of talking by asking the students to describe an animal or something they are interested in. I asked them to add to what is said, and I ask them open-ended questions." Acknowledging that young children's beginning writing takes various forms, Anne encouraged her students to write, and she said, "I accept scribbles, drawings, letters, and any mark a student makes on the writing paper as writing."

Mike's approach to providing experiences to develop his students' skills in language and literacy were primarily based on the level of development of the students in terms of what each student could do or could not do. Like Cindy and Anne, Mike understood his federal responsibilities to teach the standards of learning in language and literacy, but he said, “ I don't want to be teaching somebody else's curriculum, and when it doesn't work, it's my fault. As long as they don't tell me how to do it, as long as they let me do it my way, I have no complaints." Some examples of daily language and literacy experiences provided for the students in Mike's class included, 
storytelling, phonics, letter recognition, print awareness, one-to-one conversations, and print concepts. When describing his instructional processes and methods, Mike said, for example, "Instead of just saying 'we have a sunny day', we write \{print \} the words and make a sentence, and we say it together as I point to the words. We use icons with the words on the word wall and the students use the pointer to point to words on the word wall. You know, everything in the classroom is labeled. I've seen kids pick up on such things. I like to focus on letters, one at a time. One thing they \{students\} understand more than anything else is their name. Once you focus on letters like that and hit their name, they love it. As long as the kids are trying to write a word, it could be their name, a letter, or it can even be a scribble; that's good. I want them to see their success."

In Amy's classroom, the students are engaged in experiences planned to provide the skills in language and literacy related to the standards of learning. She recognized the developmental abilities of her students and created the learning experiences and activities based on the needs of the students. Therefore, she selected activities that were fun, interesting, and hands-on because "I want them \{students to participate in it, be able to do it and also enjoy it. I plan most of my activities in a game format, and we play games everyday. I think the children like that and it doesn't seem like work."

A typical day of language and literacy experiences planned for Amy's students will include finger plays, songs, word-play in which the children are encouraged to talk and practice vocabulary words, storytelling, one-on-one conversations, phonics, letter recognition and formation, socio-dramatic play, and read-aloud. 
Debra, like the other participants of this study, primarily planned the language and literacy activities based on the developmental abilities of the students in her classroom. She also knew that she was required to teach the standards of learning so that her students acquire the necessary skills in language and literacy. Debra was guided by some principles when she selected the experiences for the students. According to her "The activities depend on the children; there are different needs for each child. You have to look to their age, where they are developmentally, and then work from there, what they are interested in and then find books that they are interested in for some language and literacy skills."

Debra used different methods for developing the literacy and language skills of her students. "There is a lot of reading; that's the main thing. The students like being read to. I like that too, so I read to them at least twice every day during circle time. We have small and large group reading time, and there are books in all the areas of the classroom. It's nice working in small groups because it is easier to work on a specific skill with a child. I take them to the library; we use puppets, flannel board stories that I introduce, and the kids continue it - kids love it. We use a lot of conversation; our mealtime is great for conversations. We learn to take turns and not to all talk at the same time. I also use conversations as transitions for activities. We say sentences and I write \{print \} what we say on strips of writing paper and we read the sentence together; actually, they repeat after me initially. This will help the kids learn that when they talk, they say words and words have meaning." 
Other language and literacy experiences provided in Debra's classroom for the students included letter recognition, handwriting, socio-dramatic play, and letter formation.

Summary. All the Head Start teachers seemed to provide a varied repertoire of language and literacy experiences for their students. Some similarities appeared to exist between the types of activities the students engaged in at Head Start including, phonemic awareness, letter recognition and formation, talking/conversation, and read-aloud. There were also different teaching styles and methods used by individual Head Start teachers.

Research Question 5. What changes occurred in Head Start teachers' provisions of literacy and language experiences for their students because of Project STEP?

At the time of this study, the participants had all received two separate sessions of the STEP (Strategic Teacher Education Program) training. The local Mentor-Coach delivered the training.

\section{The Usefulness of Project STEP.}

Cindy endorsed Project STEP because, "I like the way they are doing the training. We do a lot of hands-on. In the past, they handed you a stack of papers and said 'here'. While I can read the printed materials, I like being able to come back and share the ideas with the other teachers. Being able to see how other teachers are doing it; which is something we really didn't do that much of before." Cindy said that she had learned some new ideas from the STEP and at the same 
time had learned to do some old things better such as "paying more attention to how I print and trying to print better." From the training she had learned different ways to incorporate language and literacy in the daily activities and routines of her class to meet the standards of learning in language and literacy. She pointed this out and said, "It simplifies the outcomes so that you can fit them in the daily routine, schedule, weekly planning, to fit the needs of your children. I have learned to provide visual images \{icons\} for the children to help them learn a little more and still have fun, to have puzzles and shapes for the children to take apart and put back together to help them learn math skills, using my finger to model or trace words from left to right and when I read, and making experience charts on which we write, for example, what we do on a field trip for discussions because it's not enough to just talk about it."

Although Anne said she found a lot of the ideas from STEP to be "pretty basic, just things you would automatically do in the classroom as a teacher", she too had found the training useful in terms of how to "implement language and literacy in the classroom and ideas on how to chart children's progress." Commenting on this, Anne said, "I have used the guidelines on how to set up a portfolio for a child and what types of information should be in it, and I have used the score cards on phonemic awareness and book awareness. I found these specific ideas to be very useful to me."

Mike also endorsed Project STEP and said, "I looked at our Head Start \} standards, and I think we aim a little too low. If they are going to push it higher, I think that's good." Mike said that he found the training to be helpful because "it gave me some useful new ideas for 
the classroom." Some of what he learned from the training included "having lots of books in all the centers in the classroom for the children to read, the word wall, and the focus on language and literacyI always thought that we should do more of those."

While Mike seemed to like the STEP training, he had some concerns about it. He pointed this out and said, "If project STEP will help me accomplish the language and literacy goals, then I'm all for it, but if they tell me to do it their way, then that is not good. I don't want to be teaching somebody else's curriculum, and when it doesn't work, it's my fault."

Amy thought that the STEP training helped to remind her of a lot of things such as "things I learned in college that I forgot about once I got here Head Start \} until I read the STEP manual and it 'refreshed it' \{my memory\}". Anne also endorsed STEP adding, "It gives you specific activities to do as well as ideas on how to modify their ideas. I really enjoy incorporating those ideas in my classroom."

Some of the ideas Amy found useful included "using the word wall with the icons so that it was easier for the young child to connect the two, the more language approach such as the daily reporter- the kids absolutely love that because it encourages each child to talk about what she or he is interested in, and journal activities in which kids write, in scribbles, actual letters, or copying words off the word wall."

Debra thought that the STEP was useful. "I think the program is a really good program." While it had "lots of ideas" she thought it helped her realize that some of what she had done in the past were appropriate. Debra noted some specific language and literacy activities she said were especially useful to her. The activities she 
learned from the training included "class generated books. That is taking a theme under study and having the students talk and write about it together. Maybe only two or three will actually write anything in their journals, but just having the experience of holding the pencil and being able to use those fine motor skills, just practicing it was wonderful. We had the author's chair, a chair in which a child sat and dictated his or her story to the teacher, and taking a lot of work samples from each student for individual portfolios." Debra said that the training had made her do some activities she did in the past differently now. For example, she spoke of always having a review discussion with the students during class but "I would have never written it down for them and now I do. I like the idea that they are seeing it being written, that these letters make words, seeing the three-year-old being able to do their left to right progression; that's great."

Looking to the future and her goals for her students in language and in literacy, Debra said, "Yes, Project STEP is making me do a lot more things than I did before but now I'm thinking - I want to do this - I want to do that - using and changing a lot of things I do in my classroom, still using some of the things I had, but implementing a lot of different things too."

With regards to Project STEP, Patty said, "I think the whole thing is useful so long I can adapt it to the needs of the teachers and students." Patty also reflected on the teachers' response to STEP training and the language and literacy requirements for students. She believed that the teachers were capable to implementing and achieving the standards of learning in their classroom but some needed guidance. 
Of the teachers needing guidance she said, "I think they \{teachers\} make it harder. They are expecting it to be all this extra stuff when they don't understand it's just a way of doing your activity versus a whole new activity."

Summary. Project STEP training appeared to have generally made a positive impact on Mike, Amy, Cindy and Debra. These Head Start teachers said that the training information was useful. Anne also said that she found some information and ideas useful. Changes appeared to exist in the content of what the teachers taught, the methods they used during teaching, and the strategies used by each teacher because of the Head Start teacher's participation in Project STEP training.

Other Topics Emerging From The Data Individualized Education Plan

There were five Head Start teachers in this study and they all had children in their classrooms with individualized education plans (IEP). Cindy had a total of twenty students of which five had IEPs. In Anne's class, there were a total of twenty students, and five had IEPs. Mike had twenty students, and five had IEPs. Amy had twenty students and seven had IEPs. Debra had twenty students and six had IEPs. The teachers were concerned about these children relative to the requirements of the National Reporting System and whether they, as teachers, would be held accountable for those students whose assessment results may be low.

The National Reporting System requires all Head Start Centers to assess all four and five year old students enrolled at Head Start. For 
example, Amy said, "I have several kids with IEPs, and I'm not really sure if they will be held accountable the same as other children in the classroom or if they will be up to the assessments. It kind of worries me if they will be held accountable. It will be an unfair assessment of the teacher based on the results that are given from the assessment of the students. It's going to be an unfair assessment of teachers in a way of getting rid of centers based on whether they meet assessment criteria or not."

Amy's last comment raised another question about how exactly the HHS will use the student data when it evaluates the contracts of local Head Start agencies judged by HHS to be deficient based on the students' assessment results. Anne also said, "It's not fair; it's not really fair to the children because they come from low-income homes, and it's hard to expect each child to come to kindergarten knowing all what are expected of them; it's just not fair."

\section{Parent Involvement.}

All the teachers expressed that parent-teacher collaboration was a concern. The teachers seemed to want the parents of their students to collaborate with them, but the level and type of parentteacher collaboration was varied among the Head Start teachers. For example, Debra said, "It will be good to get a response sometimes when you send a note home." Anne made her comments relative to the parents of a student in her class with disruptive behaviors, as "the parents never came even though I contacted them." Cindy also made another comment relative to parents. She said, "I wish we could involve them more in literacy so that they know what's going on." 
Policy makers would need to address these concerns because the concerns may become relevant if the partnership between Head Start and the states were to become a viable reform in early childhood education in the future.

\section{Disruptive Student Behavior}

The behavior of students was another concern the Head Start teachers expressed. The behaviors were varied but all were disruptive to the rest of the students, and teachers had to take time off from teaching to address disruptive student behaviors.

The teachers felt that in order to be effective in meeting the requirements for language and literacy skills development for their students, contact time for instruction with the students was critical. For example, Anne said, "I had a boy and every day, for an hour to two, I had to hold him. I was not able to teach the rest of the class because he'll go around hitting every child in the room. I'll take him and try to talk to him and tell him how wonderful and special he is and he'll just be kicking me, hitting me, and spitting on me. Everyday, I went home black and blue. He was finally removed from my class and put in another teacher's class."

Cindy also said, "Head Start is changing but the behaviors of the children are getting worse. They curse, sometimes stab others with the pencils, and get in fights. Sometimes I think the President should come and just spend a day and actually see some of the behaviors we have to put up with. Head Start has some policies you know, we have to work with these kids. I think this is a problem that will definitely come up with the Good Start, Grow Smart." 
Again, policy makers would need to address these concerns because the concerns may become relevant if the partnership between Head Start and the states were to become a viable reform in early childhood education in the future.

\section{Summary}

Through the descriptions and narratives in this chapter, portraits of the Head Start administrator, teachers and their views on the impact of the Good Start, Grow Smart Early Childhood Initiative have emerged. Although the Head Start teachers used varied strategies during instruction, the impact of the Good Start, Grow Smart was significant. In the next chapter, the portraits of the teachers are related to the wider issues raised in the Review of the Literature, and implications are made for education and research. 
Chapter 5

\section{Implications}

This chapter summarizes the process used by the investigator to develop this study; gives the philosophy of the Head Start teacher and how the teachers applied their philosophies during the instruction of language and literacy at Head Start; gives the Head Start teachers' views on the impact of the Good Start, Grow Smart Early Childhood Initiative relative to the accountability of the teachers for the achievement and success of their students in learning language and literacy skills; gives the types of language and literacy experiences the teachers provided for their students and how useful Project STEP training was to the Head Start teachers; draws implications of those issues for Head Start teachers and students; and suggests directions for future research.

\section{Process of the Study}

The purpose of this study was to investigate and analyze the views of Head Start teachers on the impact of the Good Start, Grow Smart Early Childhood Initiative on accountability for early literacy and language skills of Head Start children in a western Maryland community. Five research questions were formulated to investigate the Good Start, Grow Smart as a reform mechanism and how it influenced the educational and instructional practices of Head Start teachers during language and literacy classroom experiences with their students. 
The study included five separate one-hour interview sessions with five current Head Start teachers and an administrator. The interviews were done after the teachers had participated in the Strategic Teacher Education Program (STEP), a multi-faceted professional development training for Head Start teachers in literacy and language. The study also used the questionnaire with each of the Head Start teachers. Each teacher recorded his or her written responses to the items on the questionnaire.

The data were analyzed by the phenomenological method adapted from Hycner (1989) and were systematically interpreted in relation to the research questions in keeping with the Head Start teachers' perspectives on the Good Start, Grow Smart Early Childhood Initiative.

\section{Head Start Teachers' Philosophy}

Competent adults influenced the participants in this study. These competent adults treated each participant as an individual and considered his/her needs beginning early in the lives of the participants. Those adults, whether they were family members or teachers, had similar characteristics and qualities. According to the Head Start teachers, the adults who had influenced them the most were caring, consistent, dependable, exciting, always treated them as individuals, fun, respectful, patient and always reinforced their efforts, and those adults were nurturing. Similar qualities and characteristics were apparent in the Head Start teacher's beliefs about their work and about their students.

As the Head Start teachers approached their tasks as teachers, they tended to believe that the developmental needs and interests of 
each child was important and should be considered when planning activities. For example, Cindy said "You have to take the child from where he or she is and help him/her grow. It's individualized; it depends on the child's individual needs; what they can and can not do."

The teachers believed in having individual goals for the students and allowing the student to develop and grow at his or her own pace. Anne pointed this out. "If a child comes to school in diapers and becomes potty trained by the end of the year, that was my goal for that child. Another child may not be able to identify fifteen letters of the alphabet, but he/ she can play with another child without spitting or hitting, that was my goal for that child."

Since young children are active and curious, the Head Start teachers believed in creating activities that were fun, interactive, and hands-on to engage the children's developing senses. They used games, puppets, and storytelling using the felt board and cutout felt characters. The teachers provided opportunities for their students to talk. Amy said, "I plan most of my activities in a game format and we play games everyday. I want them \{students\} to participate in it, be able to do it and also enjoy it. I think the children like that and it doesn't seem like work".

The teachers believed the students came from low-income homes where the students sometimes did not have responsive adults in their lives. As such, the teachers believed it was their responsibility to be responsive to the students' emotional needs as well as emphasize it the emotional development of the students during instruction.

Finally, the Head Start teachers believed that they were role models for their students. As such, they took time carefully planning 
daily what they were going to do such as the themes and topics, and the strategies and procedures for how they were going to accomplish specific instructional tasks in the classroom.

Head Start Teachers' and Administrator's Views on the Impact of the Good Start, Grow Smart Early Childhood Initiative

The Head Start teachers and administrator expressed mixed views on the Good Start, Grow Smart Early Childhood Initiative. First, all the Head Start teachers said that the initiative was a change that impacted the way they planned for instruction and the change will result in adding to their workload. This view of the Good Start, Grow Smart was best expressed by Cindy as she said, "When you work for the government, they change things, they change the paperwork every couple of years. Since l've been here, they've changed the screen about five times. But that's good because it shows the growth and aiming for another direction."

Secondly, they all said that the change brought on by the initiative essentially took nothing away from Head Start as it is currently operated. However, language and literacy were being added to the current Head Start curriculum. An example of this view was expressed by Anne, "I think the initiative will better the program. I think it is good. There is more work to be done, but I am excited about exploring new ways to use books in the classroom with the children. I don't think there is anything that we used to have in our program that we don't have; it's just been added to."

Thirdly, all the participants supported the emphasis on language and literacy skills development in Head Start (Teale \& Yokota, 2000, 
NAEYC, 1998, Slegers, 1996). All the teachers in this study have implemented the integration of language and literacy in their classroom activities for one year prior to this study. The teachers began this focus in response to the requirements of the 1999 reauthorization of Head Start when the standards of learning were mandated. "I think it's wonderful, and I wish we had done this a long time ago" was how Cindy expressed her view. Debra expressed a similar view when she said, "I think it's a good program from what I know because I do think the children do need the literacy skills- like the phonemic awareness and all that- once they get to school." Patty said, "I love it; I think it's absolutely wonderful; I can't say enough about it."

Fourth, all the participants supported the training of Head Start teachers in early literacy and language. This view was well expressed by Cindy, "I like the way they are doing the training. We do a lot of hands-on. In the past, they handed you a stack of papers and said 'here'. While I can read the printed materials, I like being able to come back and share the ideas with the other teachers. Being able to see how other teachers are doing it - which is something we really didn't do that much of before."

However, Patty noted that most of the teachers had four-year college credentials, and the training topics weren't very challenging for those teachers. She said, "A lot of the teachers are saying we don't need it, and I don't appreciate being forced into training I don't need." Therefore, she suggested that STEP training be designed for specific populations based on the specific instructional needs of the population. She hoped that the Head Start Bureau for future training would 
conduct appropriate needs assessments for individual Head Start agencies prior to training Hawley \& Valli, 1999).

Fifth, all the participants supported the third major area of the initiative, sharing information between teachers, caregivers, and parents.

The Head Start teachers and administrator expressed three views on partnering with states to improve early childhood education, the second major area of the initiative. Those views were expressed as concerns of the participants and included funding, uses of the national assessment results, and job security.

J ob security was a concern expressed by Cindy. Without a fouryear college degree, Cindy felt threatened by the proposed state control over Head Start. She believed that without a four-year degree, she might lose her job and livelihood. Cindy felt particularly threatened because one of the State's requirements for teacher certification was a four-year degree, and without it, she would not have a teaching job.

Another concerned was that with state control, Head Start will lose it's comprehensive approach to working with low-income students and families because funding for such programs may be diverted to other areas the states found to be essential. In Patty's words, "Keep me up to date on current trends, tell me what to do and monitor what I do, but don't take away my funds. BOE \{Board of Education\} is completely off the page on how to educate very young children. I don't want them $\{\mathrm{BOE}\}$ to say to me 'here's how it should be' and we Head Start \} will be like them. I don't want that at all."

Also, the social and emotional well being of the students, an area of primary focus in Head Start for young children's development, might 
be lost with more emphasis placed on the academic achievement. The teacher's believed that socialization was essential for the Head Start students because of the students' low-income background and for the student's individual emotional development.

Finally, the teachers were not confident about how the HSS intended to use the students' test results from the National Reporting System on Child Outcome (Linn, 2000).

The teachers said the test could be unfair to students because all four and five year old children were required to be tested without any exceptions. Since each teacher had students with IEPs in the classroom, the teachers believed that those children with IEPs should not be assessed with the same instruments, and in the same way as the students without IEPs. They said the students' results would vary due to the requirements of individual student IEPS and other at-risk factors that could cause the student to perform below expectations.

Therefore, the Head Start teachers and administrator said the test would be "unfair" to them if the students' results were used by the HHS to determine the effectiveness of the program whenever the center was evaluated due to the different needs of students with and without IEPS.

Assessment and Accountability

While there was an established standard for accountability, the Head Start teachers demonstrated accountability in three different, but specific ways, in this study. The three ways in which accountability was demonstrated were, (1) as a Federal requirement, (2) as meeting the needs of their students and the families, and (3) as a way of fulfilling personal goals. 
To accomplish the federal requirement, every teacher knew that all instructional activities must focus on literacy and language and those activities must include specified skills outlined in the standards of learning.

The teachers constantly tried to find a balance between what the child could do based on the child's developmental needs and the expectations of the program. For example they said, "It depends on the child." Anne said, "How can you teach when a student is running around and hitting others?" Such statements suggested the frustration the teachers may be experiencing as each adapts instruction to focus on language and literacy skills activities in the classroom. With the emphasis for student's success being placed on learning specific academic skills, the teachers seemed to be feeling pressured to ignore the needs of the student and focus more on the academic skills (Sigel, 1987, Douvan, 1986). The Head Start teachers seemed to be in search of a comfortable balance as they endeavor to demonstrate accountability for teaching the students language and literacy skills and, concurrently, meet the developmental needs of their students (Neuman \& Clay, 2000, Bendura et. al. 1999, NAEYC, 1997).

Finally, the teachers said that each student was able to accomplish something because tasks were appropriately designed by an adult who considered the needs and interest of the students. The adult that does this possesses the appropriate knowledge, skills and dispositions to do so suggesting a certain level of competence (Katz, 1995, Bruner, 1996). Each teacher spoke of the time they spent planning for instruction and about instructional experiences that the students loved and had fun doing. While the methods and strategies 
embedded in the written plan suggested the teacher's goals, the successful accomplishment of the planned activities by the students suggested the competence of the teacher. Thus, in all such activities, the teacher demonstrated competence, thereby satisfying a personal goal. Anne, for example said "If a child came to class in diapers and at the end of the year is potty trained, that was my goal for that student." Another example was given by Cindy as she spoke about why she made a specific plan and said “...I want them \{students\} to see that their thoughts can be written in print ... and their thoughts mean something."

The Head Start teachers demonstrated accountability for teaching skills in two specific areas in this study, namely, language and literacy. To accomplish this, the Head Start teachers employed various methods and strategies during instruction (Meisels, Dorfman \& Steele, 1995). The data suggested that the teachers' primary methods and strategies included, (1) the integration of learning experiences through thematic units, (2) modeling and scaffolding tasks for the students, and (3) setting individual goals for individual students (National Reading Panel, 2000, Cadzen, 1983, Halliday, 1975).

Through these methods and strategies, Head Start teachers designed experiences to develop the student's skills in phonemic awareness, print awareness, increase students' vocabulary, book appreciation, letter recognition, and associate sound with written words. In short, the teachers used appropriate methods and strategies to teach the standards of learning. 


\section{The Usefulness of STEP}

The teachers said that STEP training has been "very good and useful" in several ways. First, STEP had changed the way they thought. This was pointed out by Cindy when she said, "it's like I'm relearning patterns again, I plan differently now". Secondly, the teachers said that STEP "simplified how to incorporate language and literacy skills in everything we do." A third way in which STEP was useful to the teachers was it provided step-by-step examples of appropriate activities that could be modified for use with specific groups of students.

Although all the teachers and the administrator found that STEP training was good and useful for instructional purposes, especially when teaching language and literacy skills, the training topics may not be meeting the instructional needs of some of the teachers in this study (Hawley \& Valli, 1999, Rueda, 1998). For Example Anne and Amy said that they already knew the information. Patty also indicated that she felt 'forced to do a training she didn't need'.

All the teachers in this study, except one, had undergraduate degrees in education and, therefore, may not be typical of Head Start teachers in the U.S.A. Consequently, there may be a need for multiple STEP programs to meet the instructional needs of teachers due to the various levels of the credentialing policies of Head Start teachers.

Implications of the study

The implications of the study are organized around the five research questions. Research Question one dealt with the background and personal characteristics of the Head Start Teachers. Vygotsky 
(1987) suggested "the social context was critical for children's development because social interaction promoted the development of verbal meaning." Furthermore the adults in the child's life played a role that enabled the child's growth.

The research of Teale (1982) and Van Kleeck (1990) both stressed the importance of social interaction in how children learn language and literacy. According to Teale, “... the whole process of natural literacy development hinges upon the experiences the child had in reading and writing activities which were mediated by literate adults, older siblings or events in the child's everyday life (p. 559)." The Head Start teachers interviewed, indicated they provided such an environment in which students interacted with other children with the guidance of the teacher. The accomplishments and progress of the children in learning language and literacy skills was promoted by the teachers through activities that challenged the students to think beyond the present tasks to how the student could relate the experience to everyday life. Cazden's (1983) framework for understanding language development supported the teachers' activities for language and literacy skills learning. The teachers scaffolded language and literacy skills for the students, they used games, and modeled tasks for the students during instruction.

Research Question two dealt with the reform initiative of Head Start and how the Head Start teachers viewed the impact of the reform. While the teachers generally expressed positive views about the need for students to acquire language and literacy skill, the teachers expressed some frustrations because they believed language and literacy were 'pushed' by the training, and that might negatively 
impact social and emotional development of the students who are already at-risk due to their low-income background and poverty.

The work of Sigel (1987), seemed to suggest that when school reform was based on standards, it affected both students and teachers. Teachers felt the need to alter the curriculum to meet the required standards, and other areas of the curriculum that were not emphasized languished. As Cindy and Debra responded, "We did these \{language and literacy experiences\} before, but now they want to come to your class and see that you are doing these skills." This suggests that Cindy, and the other teachers, may be doing more language and literacy activities which may negatively impact other learning goals for the students. According to Patty, due to the emphasis on language and literacy in the classroom, "our \{the students scores in math fell slightly after the 2001-2002 school year and we had to work and get the math in. I worked with the teachers on how to include math in their daily instructional plans."

On the other hand, the students were impacted by the emphasis on language and literacy and a general expression of the teachers was that "students love it." Schweinhart and Weikart (1997), and Macon, (1995) suggested that the "introduction of academic work into early childhood curriculum yielded fairly good results in the short term but may be counterproductive in the long run." This current study suggests that the Head Start teachers interviewed were focused on teaching language and literacy skills throughout the school day and will likely continue, as well as increase, their emphasis on language and literacy skills. It may be appropriate for these teachers and administrator to consider the possible risks of introducing young 
children to formal academic work prematurely. As noted by Bendura et.al (1999) in their study, the children who couldn't relate to the tasks required, felt "incompetent and even considered themselves to be stupid." Such negative self-image may contribute to negative dispositions toward the children's abilities.

Research Question three looked at how the Head Start teachers demonstrated accountability for the learning of language and literacy skills by their students. The teachers demonstrated that they were knowledgeable about appropriate methods for assessing young children. There were internal record keeping, schedules, and methods already established and were being used by the Head Start program investigated. For example, the teachers assessed the students at three different points during the school year. One such assessment was to establish a baseline to measure the students' progress and achievement, but more importantly, to used the baseline data to ascertain the individual needs of the student. The teachers seemed to believe that these baseline data will continue and perhaps some new literacy and language categories would eventually be added for assessment purposes based on the baseline data and student progress.

Research Question four considered the types of language and literacy skills related to the work the students participated in during class time. Cazden (1983), provided an excellent framework for understanding how language developed during the early years. This study suggests that the Head Start teachers interviewed applied Cazden's ideas as they scaffolded tasks for their students during 
large and small group activities, and these experiences were developmentally appropriate.

The teachers used several different ways to document the students' progress and accomplishments in language and literacy during instruction. The work sampling system (Meisels, Jablon, et al 1995) was used to focus the assessment of students on the daily activities and routines of the classroom. Each teacher used observational records and various samples of the students' work to demonstrate the student's progress. The work of Caine \& Caine (1997), seemed to suggest that the Head Start teachers made learning and assessment into an interconnected experience. Katz and Chard (1989) also noted that when learning experiences were presented through thematic units, students were provided with handson, thought provoking opportunities to construct their own meaning. However, the national assessment for language and literacy was expected to be an oral task that a staff member or teacher will present. That test was not available at the time of this study. The Head Start teachers have not used it before but were expected to do so by the HHS during the 2003-2004 school year.

Patty was expected to attend a national workshop given by HHS in the Fall of 2004 to learn about the test and how to administer it to students. Commenting on this process, patty said, "we'll see what it will be then."

Research Question five considered the usefulness of the professional training in language and literacy provided for Head Start to ensure that the teachers had the skills to teach their students. This study suggests that the teachers found the STEP training to be 
useful for planning language and literacy experiences. However, several teachers expressed that the information provided by STEP was 'basic'. Hawley and Valli (1999) provided eight principles of an effective professional development. Their first requirement for effective professional development is that "it should be driven by an analysis of teacher's goals and student performance and it should involve teachers in the identification of what they need to learn." Hawley and Valli also suggested that a needs appraisal would be necessary for the teachers in this present study to ensure that the teachers got the needed information according to their level of education, expertise, and to best serve their students. This lack of a needs appraisal appeared to be a potential weakness in the STEP as identified by several teachers in this study.

Finally, the education of young children should include experiences not only for developing skills but it should also develop, in children, positive dispositions toward learning. Bruner (1996, Katz (1987) and Smith (1990), remind educators that when we teach young children we also develop attitudes and dispositions about the use of that knowledge and those skills. Thus, the development of dispositions becomes critical for the long-term attainment of high standards by students. In the present climate of school reform, it is imperative that educators, teachers, and other caregivers consider the very nature of childhood (McGill-Franzen \& Arlington, 1993). Therefore, when writing school reform policies, the Head Start teachers and administrator interviewed, seemed to believe in the necessity of matching educational goals first to the needs of the individual child and the class. It was the concern of several of the teachers that STEP 
might not recognize the importance of this goal in Head Start and Head Start's mission.

\section{Future Directions for Research}

Children from low-come background are at risk and come to school already behind their peers. There is a need to explore assessments that are equal and fair. (Guskey), and Elmore et al. (1996) suggested that "schools can fairly be held accountable only for those factors they can control and setting some common goals for schools, not children, may be a better way for assessing accountability".

There is a need to explore the effectiveness of different strategies and methods used to teach language and literacy skills to Head Start students as provided by STEP. Teachers and educators need to know the effects of the instructional strategies on the population of low-income children. To truly determine the effects, longitudinal, quantitative, and qualitative studies need to be employed, perhaps incorporating control groups over time.

It may be appropriate for the Head Start teachers and administrator to consider the possible risks of introducing young children to formal academic work prematurely. As noted by Bendura et.al (1999) in their study, the children who couldn't relate to the tasks required, felt "incompetent and even considered themselves to be stupid." Such negative self-image may contribute to negative dispositions toward the children's abilities. More research is needed to document the impact of the required language and literacy skills on all Head Start students, and instructional strategies used by the Head 
Start teachers in this study. Such research will provide a deeper understanding of Head Start students' achievement and progress in language and literacy development.

More research is needed to determine the effects of state partnership with early childhood education including Head Start and the use of federal funds. Head Start is a multi-faceted program, and the educational community needs to know the effects such partnerships will have on each facet of Head Start including, the recruitment and retention of teachers who will provide high quality services to Head Start students.

Further research will be needed to study the issue of control and power of Head Start programs if Head Start is to form a partnership with the states in the education of low-income students such as those who currently attend Head Start. The nature of how each Head Start program will be impacted but continue to retain its unique characteristics as a Head Start program need thorough empirical, as well as qualitative data for the analysis of such impact on Head Start students, teachers, and administrators.

Research is also needed to determine specific types of professional development for Head Start teachers that would be broad-based so that the teachers are enabled to create effective partnerships with the families of the students and the community. Research is also needed to diversify the STEP to meet the various instructional needs of Head Start Teachers due to differential credentials.

Based the interviews with the Head Start teachers, the STEP appeared to be well developed and overall, positively received by the 
teachers and administrator interviewed in this study. This group of teachers had strong backgrounds in education and it is possible that they were not typical of most Head Start teachers across America. Therefore, the call for a needs assessment that is better matched to their experiences and those of their students may not reflect a lack of a needs assessment in preparing STEP but a need for multiple STEP programs.

Finally, this study has considered the work of Hawley and Valli (1999), Stiggins (1994), Meyer (1996), and Katz and Chard, (1989) in relation to performance assessment, professional development, and the reform initiative, the Good Start, Grow Smart, focused on young children and teachers of young children. As Head Start broadens it curriculum, more research will be needed to ascertain whether adding more, including language and literacy, to the curriculum is better for Head Start students. Research will also be needed to focus on whether the skills emphasized, language and literacy, prepared young children with the skills they need to enter school. 


\section{References}

Adams, M. J. (1990). Beginning to read: Thinking and learning about print. Cambridge, MA: Bolt, Beranek, \& Newman, Inc.

Administration for Children and Families. (2003). Head Start National Reporting System. Washington, DC: Author.

Allegany County HRDC. (2002). Human resources development center Head Start early childhood observation record. Maryland, Allegany County: Author.

Anderson, R. C., Heibert, E. H., Scotts, J. A. \& I.A.G. (1985). Becoming a nation of readers: the report of the commission on reading. Washington, DC: National Academy of Education.

August, D., \& Hakuta, K. (Eds.). (1998). Educating language minority children. Washington, DC: National Academy Press.

Bendura, A., Pastorelli, C., Barbaranelli, C. \& Caprara, G.V. (1999). Self-efficacy pathways to childhood depression. Journal of personality and Social Psychology 76 (2), 258-269.

Bredekamp, S. \& Copple, C. (1997). Developmentally appropriate practice in early childhood programs. (Rev.ed.) Washington DC: National Association for the Education of Young Children.

Bruner, J. (1999). Keynote address. In Global perspectives on early childhood education. A workshop sponsored by the committee on Early Childhood Pedagogy, National Academy of Sciences, and the National Research Council (pp. 9-18). Washington, DC.

Caine, R. N., \& Caine, G. (1997). Education on the edge of possibility. Alexandria, VA: Association for Supervision and Curriculum Development. 
Cazden, C. B. (1983). Adult assistance to language development: Scaffolds, models, and direct instruction. In R. P. Parker \& F. A. Davis (Eds.), Developing literacy: young children's use of language (pp. 3-18). Newark, DE: International Reading Association.

Clay, M. (1975). What did I write? Auckland, New Zealand: Heinemann Educational.

Coffman, W. E. (1993). A king over Egypt, which knew not J oseph. Educational Measurement: Issues and practices 12 (2), 5-8.

Commission on Chapter 1. (1993). Making schools work for children in poverty. Education Week 12 (16), 46-48.

Conley, D. (1993). Roadmap to restructuring: Policies, practices, and the emerging visions of schooling. Eugene, Oregon: University Press.

Council for Exceptional Children. (1996). Reading: The first chapter In education. [Online]. Available: http:// www.cec.sped.org/ frstchap.html. [1998, March].

Denzin, N. K. (1989). Interpretative interactionism. Newbury, Park, CA: Sage.

Douvan, E. (1985). The age of narcissism. In J. M. Hawes \& N. R. Hines (Eds.), American childhood, a research guide and historical handbook.

Education Week. (1997). Quality counts: A report card on the condition of public education in the 50 states. A supplement to Education Week, 16.

Elkind, D. (1986). Helping parents make healthy educational choices for their children. Educational Leadership 44, 36-38. 
Elmore, R. E., Abelman, C. H., \& Furhman, S. H. (1996). The new accountability in state education reform: from process to performance. In H. F. Ladd (Ed.), Holding schools accountable: performance-based reform in education (pp. 65-98). Washington, DC: The Brookings Institution.

Ferreiro, E. \& Teerosky, A. (1983). Literacy before schooling. New Hampshire: Heinemann Educational Books.

Fillmore, L., \& Snow, C. (2000). What teachers need to know about Language. Washington, DC: National Academy Press.

Gall, M. D. , Borg, W. R. , Gall, J. (1996). Educational research: An Introduction. White Plains, NY: Longman Publishers USA.

Glazer, S. M. \& Burke, E. M. (1994). An integrated approach to early literacy: literature to language. Boston: Allyn \& Bacon.

Goodman, K. (1986). What's whole in whole language? A parent/teacher guide to children's learning. Portsmouth, NH: Heinemann Educational Books.

Guskey, T. R. (1994). High stakes performance assessment:

Perspectives on Kentucky's reform. Thousand Oaks, CA: Corwin Press.

Halliday, M. A. K. (1975). Learning how to mean: exploration in the development of language. London: Edward Arnold.

Hawley, W. D., \& Valli, L. (1999). The essentials of effective professional development. In L. Darling-Hammond \& G. Sykes (Eds.), Teaching as learning profession: Handbook of policy and practice. (pp.127-150). San Francisco: Jossey-Bass.

Head Start Bureau, Administration for Children and Families, U.S. Department of Health and Human Services. (2001a). Head Start 
FACES: Longitudinal findings on program performance. Third progressive report. Washington, DC: DHHS.

Head Start Bureau, Administration for Children and Families, U.S. Department of Health and Human Services. (2000). The Head Start path to positive child outcomes. Washington, DC: Author.

Head Start Bureau, Administration for Children and Families, U.S. Department of Health and Human Services. (2001). "Head Start Outcomes Framework". Head Start issue 70, screening and assessment in Head Start. Washington, DC: Author.

Head Start Bureau, Administration for Children and Families, U.S. Department of Health and Human Services. (2000). Head Start National Reporting System on Child Outcomes. Washington, DC:Author.

Holdaway, D. (1979). The foundations of literacy. New York: Ashton Scholastic.

Holdaway, D. (1986). The structure of natural learning as a basis for literacy instruction. In M. R. Sampson (Ed.), The pursuit of literacy (pp. 56-72). Dubuque, IA: Kendall/ Hunt.

Hycner, R. H. (1985). Some guidelines for the phenomenological analysis of interview data. Human Studies 8 (29), 279-303.

Hyson, M. (2001). “Better futures for young children, better preparation for their teachers: Challenges emerging from recent national reports."Young Children, 56(1), 60-62.

Idaho Center on Developmental Disabilities. (1996). What is emergent literacy. [Online]. Available: http:// www.ets.uidaho.edu/cdhd/ emerlit/ intro.htm [2000 April 6].

J ensen, E. (1998). Teaching with the brain in mind. Alexandria, VA: 
Association for Supervision and Curriculum Development.

Katz, L. G. (1987). Current issues in early childhood education. Trends and Issues in Education 15 (5), 18-23.

Katz, L. G. (1995). Talks with teachers of young children: A collection. Norwood, NJ : Ablex.

Katz, L. G. \& Chard, S.C (1989). Engaging Children's minds: the project approach. Norwood, NJ : Ablex .

Labinowicz, Ed. (1980). The Piaget primer: thinking, learning, teaching. Menlo Park, CA: Addison-Wesley.

Macon, R. A. (1995). Fourth-grade slump: The cause and cure. Principal 75 (5), 6-9, 19-20.

McGill-Frazen, A., \& Allington, R.L. (1993). Flunk'em or get them classified: the contamination of primary grade accountability data. Early childhood Research Quarterly 22 (1), 19-22.

McLane, J.B. \& McNamee, G.D. (1991). The beginnings of literacy. Zero to three, XII (1), 1-8.

Lyons, M \& Pinell G. (2001). Systems for change in literacy education, a guide to professional development. Portsmouth, $\mathrm{NH}$ : Heinemann.

Meisels, S. J. (1993). Remaking classroom assessment with the work sampling system. Young Children, 48(5), pp. 34-40.

Meisels, S., Dorfman, A., \& Steele, D. (1995). Equity and excellence in group-administered and performance-based assessments. In M. T. Nettles, and A. L. Nettles (Eds.), Equity and excellence in educational testing and assessment. (pp. 243-261). Boston: Kluwer Academic Publishers. 
Meisels, S. J., Jablon, J. R., Marsden, D. B., Dichtemiller, M. L., \& Steele, D. (1995). The work sampling system: an overview. Ann Arbor: Rebus Planning Associates, Inc.

Meisels, S. J ., Liaws F-r., Dorfman, A. B., \& Fails, R. (1995). The work sampling system: reliablity and validity of a performance assessmentfor young children. Early Childhood Research Quarterly 10 (3).

Merriam, S. B. (1988). Case study research in education: A qualitative approach. San Francisco: J ossey-Bass Publishers

Meyer, R. H. (1996). Comments on chapters two, three, and four. In H. F. Ladd (Ed.), Holding schools accountable: Performance-based reform in education (pp. 137-145). Washington, DC: The Brookings Institution.

Minuchin, P. (1987). School, families, and the development of young children. Early Childhood Research Quarterly 2, 245-254.

National Association for the Education of Young Children. (1998). A joint position statement by NAEYC \& International Reading Association.: Learning to read and write: Developmentally appropriate practices for young children. Young Children, 53(4), 30-46.

National Commission on Excellence In Education. (1983). A nation at risk: The imperative for educational reform. Washington, DC: US Department of Education.

National Institute for Literacy. (2001). Put reading first: The research blocks for teaching children to read: Kindergarten through grade 3. Washington, DC: Author. 
National Institute of Child Health and Human Development (2000).

Report of the Reading Panel. Teaching children to read: An evidence-based assessment of the scientific research literature on reading and its implications for reading instruction. Washington. DC: Author.

National Research Council. (1998). Preventing reading difficulties in young children. Washington, DC: National Academy Press.

Neuman, S. \& Bredekamp, S. (2000). Becoming a reader: A developmentally appropriate approach. In D. S. Strickland \& L. M. Morrow (Eds.), Beginning reading and writing, Language and literacy series. (pp. 22-44). Newark, DE: International Reading Association.

Neuman, S., Copple, S. \& Bredekamp, S. (1999). Learning to read and write. National Association for the Education of Young Children. Nyberg, J. (1996). Charts for children print awareness activities for young children. Glenview, IL: Good Year Books.

Olson, L. (1998). An "A" or a "D": State ranking differ widely. Education Week, 17 (1), p. 18.

O'Neal, J. (February, 1991). Drive for national standards picking up steam. Educational Leadership 48 (5), 4-8.

O'Neal, J. (February, 1993). Can national standards make a difference? Educational Leadership 50 (5), 4-8.

Piaget, J . (1952). The Origins of intelligence in Childhood. New York: International University Press.

Piaget, J . (1955). The language and thought of the child. New York: Meridian. 
Raimi, R., \& Braden, L. (1998). State mathematics standard: An appraisal of science standards in 46 states, the District of Columbia, and Japan. Washington, DC: The Thomas B. Fordham Foundation.

Ratcliff, N. (1995). The need for alternative techniques for assessing young ciildren's emerging literacy skills. Contemporary Education 66 (3), 169-171.

Ravitch, D. (1992). National standards and curriculum reform: A view from the Department of Education. NASSP Bulletin 76 (548), 2429.

Rueda, R. (1998). Standards for professional development: A sociocultural perspective. (Research brief No. 2). Santa Cruz, CA: University of California, Center for Research on Education, Diversity \& Excellence.

Schickedanz, J. A. (1986). More than the ABC's: the early stages of reading and writing. Washington, DC: National Association for the Education of Young Children.

Schickedanz, J. A. (1998). What is developmentally appropriate in early literacy? Consider the alphabet. In S. B. Neuman \& K. A. Roskos (Eds.), Children achieving: Best practices in early literacy. (pp. 22-44). Newark, DE: International Reading Association.

Schweinhart, L.J ., \& Weikart, D.P. (1997). Lasting differences: The high/scope preschool curriculum comparison study through age 23. Monographs of the high/scope educational research foundation (10). Ypsilanti, Ml: High/Scope Educational Research Foundation. 
Seidman, I. E. (1991). Interviewing as qualitative research. New York: Teachers College Press.

Shepard, L.A. (1994). The challenges of assessing children appropriately. Phi Delta Kappan 76 (3), 206-212.

Sigel, I. E. (1987). Does hothousing rob children of their childhood? Early Childhood Research Quarterly 2, 211-225.

Sizer, T. \& Rogers, B. (February, 1993). Designing standards: Achieving the delicate Balance. Educational Leadership 50 (5), 24-26.

Slegers, B. (1996). A review of the research literature on emergent literacy. Urbana-Champaign, IL: ERIC Clearinghouse on Elementary Education and Childhood Education.

Smith, F. (1990). To think. New York: Teachers College Press.

Stallman, A.C., \& Pearson, P.D. (1990). Formal measures of early literacy. In L.M. Morrow and J.K. Smith (Eds.), Assessment for instruction in early literacy. (pp. 7-44) Englewood Cliffs, NJ : Prentice Hall.

Stanovich, K. E. (1993-94). Romance and reality (Distinguished Educator Series). Reading Teacher 47 (4), 280-91.

Stiggins, KR. J . (1994). Performance assessment. ERIC/ CASS Digest Series on Assessment in Counseling Therapy.

Tabors, P. (1997). One child, two languages, a guide for preschool Educators of children learning English as a second language. Baltimore, MD: Brooks.

Teale, W. (1982). Toward a theory of how children learn to read and write naturally. Language Arts, 59. 
Teale, W. (1984). Reading to young children: Its significance for literacy development. In H. Goelman \& A. Oberg (Eds.), A wakening to literacy (pp. 110-121). Exeter, NH: Heinemann.

Teale, W. \& Sulzby, E. (1986). Emergent literacy: Writing and reading. Norwood, NJ : Ablex Publishing Corporation.

Teale, W., \& Yokota, J . (2000). Beginning reading and writing: A perspectives on instruction. In D. S. Strickland \& L. M. Morrow (Eds.), Beginning reading and writing. Language and literacy series (pp. 3-21). Newark: DE: International Reading Association.

The White House. (2002). Good start, grow smart: The Bush administration's early childhood initiative. The White House: Author.

The White House. (2002). The no child left behind act. The White House: author.

U. S. Department of Health and Human Services (2002). National Head Start S.T.E.P. teacher's manual. Washington, DC: Author.

U. S. Department of Health and Human Services (2002). Head Start history. Washington, DC: Author.

U. S. Department of Health and Human Services (2003). Poverty guidelines. Federal Register, 68 (26), pp. 6456-6458.

U. S. Department of Health and Human Services (2000). Head Start performance Standards. Washington, DC: Author.

van Kleeck, A. (1990). Emergent literacy: Learning about print before learning to read. Topics in Language Disorders, 10 (2), 25-45. 
Vygotsky, L. S. (1962). Thought and language (Ed. and Trans. by E. Haufman \& G. Vakas). Cambridge, MA: The M. I. T. Press and J ohn Wiley \& Sons, Inc.

Vygotsky, L. S. (1978). Mind in society: The development of higher psychological processes (M. Cole, V. John-Steiner, S. Scribner \& E. Souberman, Eds.). Cambridge, MA: Harvard University Press.

Vygotsky, L. S. (1987). The collected works: Vol. 1. Problems of general psychology (R. W. Rieber \& A. S. Carton. Eds.). New York: Plenum Press.

Wells, G. (1986). The meaning makers: children learning language and using language to learn. Exeter, $\mathrm{NH}$ : Heinemann.

Welsh, P. (Spring, 1992). It takes two to tango. American Educator 16 (1), 18-23. (pp. 114-119). Westport, CT: Greenwood.

West, L. \& Egley, E. (1998). “Children get more than a hamburger: Using labels and logos to enhance literacy."Dimensions of Early Childhood, Summer/ Fall.

Whitehurst, G. \& Lonigan, C. (1998). Child development and emergent literacy. Child development, 68, 848-872.

Winn, M. (1981). Children without childhood. New York: Pantheon Books. Yopp, H. K. (1992). Developing phonemic awareness in young children. Reading Teacher, 45 (9), 696-703. 


\section{Appendix A}

\section{Cover Letter}

Teachers' Views of the Impact of the Good Start, Grow Smart Early Childhood Initiative on Head Start Programs in a Western Maryland

Community

\section{To Whom It May Concern}

I am Fannia L. Boayue, a candidate in the doctoral program of study in education at West Virginia University.

I am conduction a research project on Head Start teacher's views on the impact of the Bush Administration's Good Start, Grow Smart Early Childhood Initiative announced by President Bush in April, 2002. The purpose of the study is to investigate and analyze the views of Head Start teachers on the impact of the Good Start, Grow Smart Early Childhood Initiative on accountability for early literacy and language skills for Head Start children. This research is in partial fulfillment of the requirements for the degree of Doctor in Education, ED.D.

All data given and collected from you will be kept strictly confidential and will contain to details that could be used to identify you. Your written responses to questions and audio-recorded interview will form the data for this research. Your participation in this research is voluntary. You have the tight to quit the study if you desire and you have the right to decline to answer any of the questions. Notes and recordings of interview will be kept by the investigator and used only for research purposes.

You may contact me at (301) 687-4220 of at fboayue@frostburg.edu. Thank you for your participation and time.

Sincerely,

Fannia L. Boayue 


\section{Appendix B}

\section{Consent Form}

Teachers' Views of the Impact of the Good Start, Grow Smart Early

Childhood Initiative on Head Start Programs in a Western Maryland

Community

\section{To Whom It May Concern}

I, Name, have been asked to participate in this study, a research to fulfill the requirements for a doctoral dissertation in curriculum and instruction at West Virginia University, which has been explained to me by Fannia L. Boayue.

I have been told that the purpose of this study is to investigate Head Start teachers' views about the impact of the Bush Administration's Good Start, Grow Smart Early Childhood Initiative.

This study involves adults as participants. I will be given a questionnaire to respond to and participate in a one-hour person-toperson audio taped interview. It will take about thirty minutes for me to answer the questionnaire and I do not have to answer all of the questions. At the time of the interview, I have the right to decline to answer any of the questions.

There are no known or expected discomforts from participating in this study. The study will be of value to teachers in planning for instruction to promote positive school experiences for children in early childhood classrooms and encourage the dialogue between parent, teachers, and administrators for preparing children for school success.

All data collected and given will be kept strictly confidential. I understand that any reports prepared using the information obtained in the study will not contain details that could be used to identify me. I, therefore, consent to publication of the study results for research purposes. I have been informed that notes and recordings of the interview will be kept by the researcher and will only be used for research purposes. 
I have been told that I do not have to be in this study if I don't want to be. I have the right to quit the study if I desire. I have been allowed to ask any questions

about the study and all questions have been answered. I will receive a signed copy of this form. I can contact Fannia L. Boayue at (301) 7228428, or her academic Chairperson, Dr. Joy Faini Saab, at (304) 2933441 , for more information about this study. I willingly agree to be in this study.

Signature of subject

Date $\quad$ Time

Signature of Investigator

Date $\quad \overline{T i m e}$




\section{Appendix C}

Interview Questions for Head Start Teachers

Teachers' Views of the Impact of the Good Start, Grow Smart Early Childhood Initiative on Head Start Programs in a Western Maryland Community

1. What is your understanding of the Good Start, Grow Smart Early Childhood Initiative? What are some things that interest you about it?

2. How do you think the Good Start, Grow Smart Early Childhood Initiative will impact you as a teacher? What impact will it have on you in language and literacy?

3. What characteristics of the Good Start, Grow Smart Early Childhood Initiative is/are similar to the current Head Start Program?

4. What characteristics of the Good Start, Grow Smart Early Childhood Initiative is/are different from the current Head Start Program.

5. Describe how you determine a plan for literacy development for your students.

Probe) 1. What are you doing now that will help your students learn literacy skills? 2. What are some literacy activities you currently use? 3. How often do you use or practice this activity?

6. Describe how you determine a plan for language development for your students?

Probe) 1. What are you doing now that will help your students learn language skills? 2. What are some language activities (i.e. conversation) you currently use?

7. Is there anything that you feel you or the program need to do to prepare your students for school?

Probe) 1. Do your students need to know or be able to do anything before they begin school? 2. What do you think you or 
the program would need to do specifically to prepare your students for school?

8. Reflecting on your past experiences as a pre-service teacher, what experiences do you remember that may have shaped your decision to work as a Head Start teacher?

9. Reflecting on your past experiences, what educational or other experiences have you had as an adult that have influenced the way you approach your tasks as a teacher for young children?

Probe) 1. How do you feel now about your school experiences other than Head Start? 2. Tell me some memories about your education.

3. Tell me about your most meaningful experiences in Head Start? 4. What have been your most difficult experiences in Head Start?

10. Tell me about Project STEP. How do you think Project STEP will help you provide services to Head Start children? Probe) 1. What kinds of new things has it taught you? 2. What kinds of things will it teach you in the future? Give some examples.

11. What characteristics of Project STEP do you find meaningful or useful to you and other Head Start teachers?

12. Because of your participation in STEP, what changes have you seen in your knowledge and practice related to language and literacy? 


\section{Appendix D}

Interview Questions for Administrator

Teachers' Views of the Impact of the Good Start, Grow Smart Early Childhood Initiative on Head Start Programs in a Western Maryland Community

1. What is your understanding of the Good Start Grow Smart Early Childhood Initiative? What are some things that interest you about it?

2. What characteristics of the Good Start Grow Smart Early Childhood Initiative is/are similar to the current Head Start program?

3. What characteristics of the Good Start Grow Smart Early Childhood Initiative is/are different from the current Head Start program?

4. Is there anything you or the program need to do to prepare Head Start students for school? Probe) 1. Do students need to know or be able to anything before they begin school? What do you think you or the program would need to do specifically to prepare students for school?

5. Tell me about Project STEP. How do you think project STEP will help you provide services to Head Start children?

6. How many hours does STEP training take? How many hours have Head Start teachers in this county had? What areas/topics are covered during STEP training? Describe how you would support the Head Start teachers.

7. What characteristics of Project STEP do you find meaningful or useful?

8. What is the schedule for reporting student progress and achievement in language and literacy as mandated? 
9. Who is responsible for training the staff (teachers)?

10. How many Head Start teachers do you have on staff? How many are males or females? What is the range of credentials the teachers have?

11. What was your total enrollment during the 2002-2003 school year? Were there any students identified under IDEA or other head Start regulations as having a disability or at risk? What was the percentage of such students?

12. Reflecting on your past experiences as a pre-service teacher, what experiences do you remember that may have shaped your decision to work at Head Start?

13. Reflecting on your past experiences, what educational or other experiences have you had as an adult that have influenced the way as you approach your tasks at Head Start? Probe) 1. How do you feel now about your school experiences other than Head Start? 2. Tell me some memories about your education. 3. Tell me about your most meaningful experiences in Head Start? 4. What have been your most difficult experiences in Head Start? 
Appendix $\mathrm{E}$

QUESTIONNAIRE

Teachers' Views of the Impact of the Good Start, Grow Smart Early Childhood Initiative on Head Start Programs in a Western Maryland Community

\section{PART I: DEMOGRAPHICS}

1. Check all items that apply to you.

_-_ male ___ female __-_ teacher ___ Other (please specify)

2. How long have you served as a teacher at Head Start?

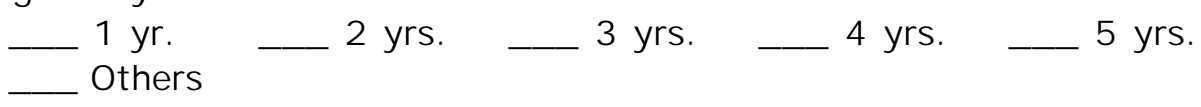

3. Which of the following credentials do you have? (check all that apply).

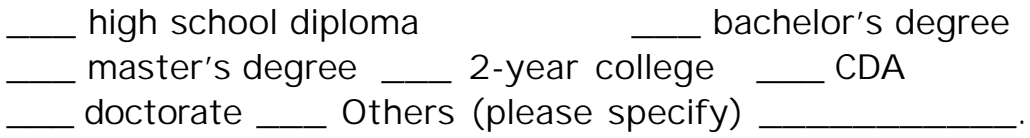

4. What is the age range of the children you currently teach?

(example: 3-4 year-olds)

5. What was the total number of students in your class during the 2002-2003 school year? students.

6. During the 2002-2003 school year, did you teach any student identified under the guidelines of IDEA (Individuals with Disabilities Education Act) as having a disability?

--- Yes _--- No

A. If "yes", how many children were identified?

\section{PART II: INSTRUCTIONAL PRACTICES}

1. For which of the following items do you provide instruction or practice to your students? (write I for instruction, $\mathbf{P}$ for practice or I/ P for instruction \& practice).

print concepts

shared reading

-_- determining knowledge of print phonemic awareness determining knowledge of books

--- one-to-one conversations

--- asking questions

--- phonics

--- socio-dramatic play

--- book appreciation storytelling letter recognition letter formation handwriting discussions read-aloud writing time writing center print awareness Others (please list). 
2. How long have used each item in your class?

Method

--- read-aloud
--- shared reading
--- determining knowledge of print
--- phonemic awareness
--- determining knowledge of books
--- storytelling
--- letter recognition
--- letter formation
--- handwriting
--- socio-dramatic play
--- print awareness
--- book appreciation
--- print concepts
--- phonological awareness
--- Others (please list)

\# of Months \# of Years

$\begin{array}{ll}-- \text { mos. } & --- \text { yrs. } \\ --- \text { mos. } & --- \text { yrs. } \\ --- \text { mos. } & --- \text { yrs. } \\ --- \text { mos. } & --- \text { yrs. } \\ --- \text { mos. } & --- \text { yrs. } \\ --- \text { mos. } & --- \text { yrs. } \\ --- \text { mos. } & --- \text { yrs. } \\ --- \text { mos. } & --- \text { yrs. } \\ --- \text { mos. } & --- \text { yrs. } \\ --- \text { mos. } & --- \text { yrs. } \\ --- \text { mos. } & --- \text { yrs. } \\ --- \text { mos. } & --- \text { yrs. } \\ --- \text { mos. } & --- \text { yrs. } \\ --- \text { mos. } & --- \text { yrs. }\end{array}$

\{Please respond in specific terms to questions 3-5 below.\}

3A. List or describe the language skills practiced by your students in class.

B. How often do your students practice the language skills in class or during school at item $3 \mathrm{~A}$ above? daily weekly once monthly Others (explain)

4A. List or describe the literacy skills practiced by your students in class.

B. How often do your students practice the literacy skills in class or during school at item $4 \mathrm{~A}$ above?

____ daily ___ weekly ___ once monthly ___ Others (explain)

5. Is there an Early Reading First program at your Head Start center? --- Yes No (if "no" go to item \#9) 
6. What is the focus of the Early Reading First program at your Head Start center? (check all that apply).

-- speaking $_{---} \begin{aligned} & \text { language } \\ & \text { literacy }\end{aligned}$

7. How long has the Early Reading First program been in use at your Head Start center? -- 4 yrs. $1 \mathrm{yr}$. 2 yrs. 3 yrs.

8. Does your Head Start center have an established system for assessing student progress? Yes No

9. Does your Head Start center have an established system for reporting student achievement? Yes No

\section{PART III: ASSESSMENT}

1. How often are you required to assess student progress?

daily
----- weekly
--- Others (explain how frequent) once monthly

2. How often are you required to assess student achievement?
--- daily weekly once monthly
-- Others (explain how frequent)

3. Does your Head Start center have an established method for evaluating student progress and achievement in language and literacy?

describe the method)

$$
\text { Yes - No No (if "yes", please specify or }
$$

4. How often are you required to assess student progress and achievement in language and literacy?
_-_ daily weekly
-_- Others (explain how frequently) once monthly 
5. Does your Head Start center have an established method for evaluating student progress and achievement in language and literacy?

describe the method) ${ }^{---}$No (if "yes", please specify or

6. How often do you assess student progress and achievement as a classroom teacher?

-_- daily _-_- weekly

once monthly

--- Others (explain how frequently)

7. To whom do you make the report on student progress and achievement in language and literacy?

(please specify)
(plenter Director

8. How often are you required to report student progress and achievement in language and literacy to parents?

daily
---- Others (explain how frequent)

\section{PART IV: STANDARDS AND PROFESSIONAL DEVELOPMENT}

1. Does your Head Start center have established standards of learning for student progress and achievement in the following areas:
A. Language
explain).
--- Yes
--- No
--_ Others (please
B. Literacy
--- Yes
--- No
--- Others (please

2. How long have you used the standards of learning in each of the following areas of instruction, (ex. Spring, 2002 - Spring, 2003):
A. Language
B. Literacy 
3. For which of the following have you been trained by STEP (Strategic Teacher Education Program)?

Early Literacy Specialist: --- Yes
Early Literacy Mentor-Coaches:

A. If you answered "yes", briefly describe your role and responsibilities.

4. Have you attended Head Start Project STEP training?

--- Yes No

A. If you answered "yes" at item \#4 above, when did you attend? (ex. Summer, 2002).

B. If you answered "no" at item \#4 above, when will you attend? (ex. Fall, 2003).

5. Which of the following experiences have you received from STEP?

$\begin{array}{lll}\text { Mentor-Coaching: } & -- \text { Yes } & --- \text { No } \\ \text { Training: } & --- \text { Yes } & --- \text { No }\end{array}$

6. List or describe the skills in literacy and language and/or strategies and methods you learned when you attended STEP training?

Language

Literacy

7. List or describe some methods for recording student progress and achievement you learned when you attended STEP training. 
8. List or describe some methods for evaluating student progress and achievement you learned when you attended STEP training?

9. As a Head Start teacher, how will you describe your understanding of the requirements of the Good Start, Grow Smart Early Childhood Initiative in each of its following component areas?

A. Strengthening Head Start:

$\begin{array}{lc}--- & \text { Excellent } \\ --- & \text { good } \\ --- & \text { minimal } \\ --- & \text { inadequate }\end{array}$

B. Partnering with States to Improve Early Childhood Education

--- Excellent

--- good

--- minimal

-_- inadequate

C. Providing Information to Teachers, Caregivers and Parents

$\begin{array}{lc} & \text { Excellent } \\ --- & \text { good } \\ --- & \text { minimal } \\ --- & \text { inadequate }\end{array}$

10. As a Head Start teacher, how will you describe your preparedness to implement the requirements of the Good Start, Grow Smart Early Childhood Initiative in your classroom?

$\begin{array}{lc} & \text { Excellent } \\ --- & \text { good } \\ ---- & \text { minimal } \\ --- & \text { inadequate }\end{array}$


11. As a Head Start teacher, how will you describe your understanding of the knowledge-base for implementing the Good Start, Grow Smart Early Childhood Initiative in each of the following areas?

Literacy:

-_- excellent

-- good

-_- minimal

--- inadequate
Language:

_-_ excellent good

-- minimal

--- inadequate

12. As a Head Start teacher, how will you describe your experiences and knowledge gained from STEP training relative to the instruction of the young children you work with in the following areas?

Literacy:

excellent

--- good

-_- minimal

--- inadequate
Language:

excellent good

-- minimal

--- inadequate 


\section{VITA}

\section{BIOGRAPHICAL INFORMATION}

First Name: Fannia Leabeh Boayue

Date of Birth: March 5, 1962

Place of Birth: Ganta Nimba County, Liberia.

\section{EDUCATIONAL BACKGROUND}

1970-1977 Primary education, Ganta United Methodist School, Ganta, Liberia.

1978-1980 High School and Diploma, College of West Africa, Monrovia, Liberia .

1981-1984 Cuttington University College, B.Sc. in education, Liberia.

1990-1992 M.Sc. in Education Administration, West Virginia University, USA.

\section{PROFESSIONAL EXPERIENCES}

1982

Appointed by the Dean of Student Affairs as Dormitory Counselor, Cuttington University College.

1983

I am selected as Cuttington University College student representative to travel to the United Nations General Assembly and to Paris, France for the meeting of the French-Speaking African nations summit.

1985-1989 Employed as Teacher at Joseph Jenkins Roberts United Methodist Elementary \& Junior High School (J) RUMS), until May, 1990 when I fled Liberia because of the civil war.

1986-1988, I was elected Secretary of the Parent Teacher Association (PTA) of JJRUMS. 
In 1988, I represented JJRUMS at a conference on "The Role of Non-Governmental Agency in the Social, Political and Economic Progress of Liberia" organized by the United States Agency for International Development (USAID).

In 1989, I was elected Vice-President of the PTA, JJ RUMS, until I fled the civil war in 1990.

1991-1997 I worked as Graduate Teaching Assistant at the Center for Black Culture \& Research and in the Department of Education, West Virginia University, USA.

1997-present I am employed as Instructor in the Department of Educational Professions, Frostburg State University (FSU), USA.

In 1999, I was a presenter at the Annual Convention of the International Reading Association.

In 1999-2000, I was a co-writer of the folio in Early Childhood Education (FSU) for review and accreditation by the National Council for the Education of Teacher Education (NCATE).

I serve on several FSU and education department committees including, Academic Standards, General Education Program, Foundations and as Liaison to several public schools.

\section{PROFESSIONAL MEMBERSHIP}

I am a member of the National Association for the Education of Young Children (NAEYC), Association for Supervision and Curriculum Development (ASCD), Phi Delta Kappa (PDK), and the Consortium for Early Childhood Teachers and Administrators in the State of Maryland, USA. 